\title{
Halka Açık Anonim Ortaklıklarda Ayrılma Hakkı
}

\author{
Neşe Ölekli
}

Öz

Çalışmamız hukukumuzda ilk defa 6.12.2012 tarihli 6362 sayılı Sermaye Piyasası Kanunu'nda ("SPK") halka açık anonim ortaklıklardaki pay sahibine tanınan ayrılma hakkı konusunu içermektedir. SPK'nın 23. maddesinde belirtilen önemli nitelikteki işlemlere veya II-23.1 sayılı Önemli Nitelikteki İşlemlere İlişkin Ortak Esaslar Ve Ayrılma Hakkı Tebliği'nin 5. maddesinde belirtilen ya da Sermaye Piyasası Kurulu tarafindan önemli nitelikteki işlem olarak kabul edilen işlemlere ilişkin genel kurul toplantısına katılıp olumsuz oy kullanan ve muhalefetini toplantı tutanağına işleten pay sahipleri paylarını ortaklığa satarak ortaklıktan ayrılabilirler. Bununla birlikte, SPK'nın 24. maddesinin 2. fikrasına göre pay sahibinin genel kurul toplantısına katılmasına haksız bir biçimde engel olunması, genel kurul toplantısına usulüne uygun davet yapılmaması veya gündemin usulüne uygun bir biçimde ilan edilmemesi hâllerinde de genel kurul kararına muhalif kalma muhalefetini toplant tutanağına işletme şartı aranmaksızın ayrılma hakkı kullanılabilir. Ayrılma hakkının kullanılması sonucunda şirket ilgili payı borsadaki ağılıklı fiyat üzerinden, paylarının borsada işlem görmemesi halinde ise değerleme raporunda belirtilen adil bedel üzerinden satın almak zorundadır. Çalışmamızda ayrılma hakkı kavramı, bu hakkın amacı, tarihçesi, kullanım şartları ve yöntemi ile bu hakkın doğması için bir ön koşul niteliğinde olan önemli nitelikteki işlemler, ayrılma bedeli ve ayrılma hakkı ile önemli nitelikteki işlemlere ilişkin zorunluluklara uyulmaması halinde karşılaşılabilinecek yaptırımlar incelenmiştir.

\section{Anahtar Kelimeler}

Halka açık anonim ortaklık • Ayrılma hakkı • Pay sahibi • Önemli nitelikte işlem • Ayrılma bedeli

\section{Appraisal Right in Public Joint Stock Companies}

\section{Summary}

This study reviews Turkish appraisal right, which was recognized for shareholders of publicly held joint stock companies in Turkey by the Capital Markets Law No. 6362 dated 6.12.2012 ("CML"). According to the law, dissenting shareholders can leave a company by selling their shares to the company. The shareholders are required to have attended a general meeting of material transactions as set forth in Article 23 of $\mathrm{CML}$ or in the Communique on Common Provisions on Material Transactions and Appraisal Rights (II-23.1). The transactions must be accepted as material by the Capital Markets Board and must be drafted by the opposition in the minutes of the meeting. Under Paragraph 2 of Article 24 of CML, there are additional guidelines in the event that: a shareholder is prevented from attending the general meeting unlawfully; the shareholder is not duly invited to the general meeting; or the agenda of the general meeting is not announced in due course. In such instances, the shareholders can exercise their appraisal rights without attending the meeting or drafting their opposition in the minutes of the meeting. Following an appraisal, the company is obligated to purchase the shares above the average price in the exchange market. For companies with shares not traded in the open market, the price will be determined as fair value by a valuation report. In this study, we review the concept, aim and history of appraisal right. As a condition precedent, we examine the conditions and material transactions that have given rise to the use of appraisal right. We also examine appraisal values and sanctions, which may be imposed due to inconsistencies with the new CML legislation.

\section{Keywords}

Public Joint Stock Companies • Appraisal Right • Shareholder • Material Transaction • Appraisal Value

\footnotetext{
Sorumlu Yazar: Neşe Ölekli (Avukat, Yüksek Lisans Öğrencisi), Türkiye Finans Katılım Bankası A. Ş. Hukuk Danışmanlık Müdürlüğü, İstanbul Üniversitesi Sosyal Bilimler Enstitüsü Özel Hukuk Anabilim Dalı, İstanbul, Türkiye. Eposta: neseolekli@hotmail.com Attf: Ölekli, Neşe; “Halka Açık Anonim Ortaklıklarda Ayrılma Hakkı”, İstanbul Hukuk Mecmuası, 76/1, 2018, 221-256.
} 


\section{Giriş}

Halka açık anonim ortaklıklarda pay sahibi, halka kapalı anonim ortaklıklarda pay sahibi için öngörülen tüm mali ve idari haklara sahiptir. Bununla birlikte, SPK'da yatırımcının korunması düşüncesinden hareketle halka açık anonim ortaklıklardaki pay sahiplerine, TTK'ya nazaran daha geniş haklar tanınmıştır. Söz konusu hakların bir kısmı pay sahibini dolaylı olarak korumaktayken, bir kısmı pay sahibini doğrudan doğruya korumayı amaçlamaktadır. Halka açık anonim ortaklıklarda pay sahibini dolaylı olarak koruyan düzenlemeler; halka açık anonim ortaklıklarda şeffaflık/ kamuyu aydınlatma ilkesinin geçerli olması, ortaklığın ilk halka arzında imtiyazların şeffaf ve anlaşılır bir şekilde kamuya duyurulması zorunluluğu, şirketin Kurul ve denetim kuruluşları tarafından denetlenmesi, karın genel kurul tarafından belirlenecek dağıtım politikaları çerçevesinde dağıtılacak olması, bağı̧̧ yapılabilmesi ve pay sahibi dışındaki kişilere kar payı dağıtılabilmesi için esas sözleşmede hüküm bulunması zorunluluğu, bağışın sınırının genel kurulca belirlenecek olması ve Kurul'un üst sınırı belirlemeye yetkili olması, kurumsal yönetim ilkeleri, örtülü kazanç aktarımı yasağ ${ }_{1}$ şeklinde sıralanabilir. ${ }^{1}$ Pay sahibini doğrudan doğruya korumaya yönelik düzenlemeler ise pay sahibinin ayrılma hakkı, pay alım teklifi, ortaklıktan çıkarma ve satma hakkı ile yatırımcının tazminidir. ${ }^{2}$

Sermayesi belirli ve paylara bölünmüş bir sermaye şirketi olan anonim ortaklıkta sermaye ön plandadır ve pay sahipliği hakları paya bağlıdır. TTK'ya göre, kural olarak pay sahibi sahip olduğu payları satarak ortaklıktan ayrılabilir. Pay sahibinin payını devretmesi bazı istisnalar ${ }^{3}$ dışında serbesttir. Ancak, azlık ${ }^{4}$ veya daha küçük orandaki pay sahipleri için ortaklık payının satılması, sahip olunan payların ortaklık ile ilgili kararların alınmasında etkili olamaması ve çoğu zaman kar payı getirmemesi nedeniyle kolay olmamaktadır. Böyle bir durumda, pay sahibinin ya payını çok düşük bir bedelle satacak veya ortaklıkta pay sahibi olarak kalmaya devam edecektir. Halka açı anonim ortaklıklarda, küçük pay sahipleri çoğunlukla birlikte hareket etme yeteneğinden yoksun olmakta, genel kurula katılamamakta ve dava haklarını kullanamamaktadır. Bu nedenle, halka açık anonim ortaklıklarda hakim ortak ile borsadan pay edinerek pay sahibi olan yatırımcılar arasındaki menfaat çatışması halka kapalı anonim ortaklıklara nazaran daha fazla önem arz etmektedir. İşte halka açık anonim ortaklıkların bu kendine özgü yapısı, küçük pay sahiplerinin menfaatlerinin

\footnotetext{
Tekin Memiş/ Gökçen Turan, Sermaye Piyasası Hukuku, 2.bs., Ankara, Seçkin Yayıncılık, 2016, s. 121,124; Nusret Çetin/ Hatice Ebru Töremiş/ Zeynep Cantimur, Sermaye Piyasası Kanunu'nun Sistematik Analizi, Ankara, Yetkin Yayınları, 2014, s. 169,170.

Çetin/ Töremiş/ Cantimur, s.170, 192.

İstisnalara örnek olarak, TTK md. 352 gereğince kuruluștan önce pay taahhüdünün devrinin ortaklığa karș1 hükümsüz olması, TTK md. 491'e göre bedeli tamamen ödenmemiş nama yazılı payların devrinin ortaklığın onayına bağlı olması ve TTK md. 492'ye nama yazılı payların devrinin esas sözleșmeyle sınırlandırılması, Bankacılık Kanunu md. 18'e göre belirli oranların üzerindeki pay devirlerinin BDDK'nın iznine tabi olması gösterilebilir.

${ }_{4}$ TTK md. 339'a göre, sermayenin yüzde onunu, halka açık ortaklıklarda esas veya çıkarılmış sermayenin yüzde beşini oluşturan pay sahipleri azlığı oluşturur.
} 
daha fazla korunmasını zorunlu kılmıştır. ${ }^{5}$ Bu konuda, 2499 sayılı Sermaye Piyasası Kanunu'nda öngörülmeyen, en önemli sayılabilecek düzenlemelerden biri SPK md. 24 'de düzenlenen ayrılma hakkıdır.

Avrupa Birliği mevzuatına uyum sağlamayı amaçlayan söz konusu düzenleme sayesinde, halka açık anonim ortalıkta, payının esas veya çıkarılmış sermayeye oranı her ne olursa olsun, her pay sahibi SPK md. 23'te öngörülen önemli nitelikte işlemlerin gerçekleşmesi halinde genel kurula katılmak, olumsuz oy kullanmak ve muhalefet şerhini toplantı tutanağına geçirmek suretiyle paylarını doğrudan doğruya şirkete satıp ayrılabilecektir. Ayrıca, ilgili maddede pay sahibinin genel kurul toplantısına katılmasına haksız bir biçimde engel olunması, genel kurul toplantısına usulüne uygun davet yapılmaması veya gündemin usulüne uygun bir biçimde ilan edilmemesi hâllerinde, genel kurul kararlarına muhalif kalma ve muhalefet şerhini tutanağa kaydettirme şartı aranmaksızın ayrılma hakkının tanınacağı düzenlenmiştir. Bu suretle, özellikle hakim ortak tarafindan yönetilen halka açık anonim ortaklıklarda paylarını borsada satma imkanı olmayan küçük pay sahiplerinin payları için likidite sağlanması ve ortaklığın kontrolüne sahip olmayan pay sahiplerinin korunması amaçlanmıştır. ${ }^{6}$

6 bölümden oluşan çalışmamızda, halka açık anonim ortaklıklarda pay sahibini doğrudan korumaya yönelik bir düzenleme olan ayrılma hakkı incelenmiştir. $\mathrm{Bu}$ doğrultuda, öncelikle ayrılma hakkının tarihsel gelişimi, amacı, niteliği ve SPK ile TTK'da yer alan benzer düzenlemeler arasındaki farklar ve benzerlikleri hakkında bilgi verilmiş, ardından hakkın doğması ve kullanılması için gereken şartlar açıklanmış, daha sonra söz konusu hakkın kullanım yöntemi ve kullanımının engellenmesi hususu incelenmiştir. Dördüncü bölümde ayrılma hakkının doğmadığ1 haller konusuna değinildikten sonra ayrılma bedeli konusu açıklanmış ve en son bölümde ise önemli nitelikteki işlemler ve ayrılma hakkı ile ilgili mevzuatta öngörülen zorunluluklara uyulmaması durumunda gündeme gelebilecek yaptırımlar konusunda değerlendirmelerde bulunulmuştur.

\section{Ayrılma Hakkı}

\subsection{Tanımı, Amacı ve Tarihsel Gelişimi}

Ayrılma hakkı, halka açık anonim ortaklıklarda alınan bazı genel kurul kararlarına karşı olumsuz oy kullanan pay sahiplerinin paylarını ortaklığa adil bir bedelle satarak ortaklığın feshine ve infisahına sebep olmaksızın ortaklık ile ilişkisini sona erdirmesidir. $^{7}$

Çağlar Manavgat, Halka Açık Anonim Ortaklıklar ve Halka Arz, Ankara, Banka ve Ticaret Hukuku Araştırma Enstitüsü, 2016, s. 317, 318; Memiş/Turan, s. 121, 122.

SPK Gerekçesi, s. 26, (Çevrimiçi) https://www.tbmm.gov.tr/sirasayi/donem24/yil01/ss337.pdf, 20 Aralık 2016.

Reinier Kraakman/ John Armour/ Paul Davies/ Luca Enriques/ Henry Hansmann/ Gerard Hertig/ Klaus Hopt/ Hideki Kanda/ Edward Rock, The Anatomy of Corporate Law, 2. bs., New York, Oxford University Press, 2009, s. 200, 
Ayrılma hakkının asıl amacı ortaklığın kontrolüne sahip olmayan pay sahibinin korunmasıdır. Bununla birlikte, doktrinde ayrılma hakkının amacı konusunda farklı yaklaşımlar bulunmaktadır. Anonim ortaklıklarda, ortaklıkla ilgili esaslı nitelikte değişiklik öngören kararların birçoğu oy birliği gerekmeksizin (nitelikli) oy çoğunluğu ile alınabilmektedir. Anonim ortaklık için önemli bir kararın oybirliği ile alınmasının gerekmemesi, pay sahiplerinin ilgili kararı bireysel olarak veto edememesini sonuçlamaktadır. Pay sahibine ayrılma hakkı tanınması sayesinde, ilgili pay sahibi sözkonusu değişikliğe katlanmak zorunda kalmamakta, payının bedelinin karşılığını alarak şirketten ayrilabilmektedir. ${ }^{9}$ Bunun yanı sıra, pay sahibine ayrılma hakkı tanınması, önemli nitelikteki genel kurul kararlarına bağlı değişiklikler sebebiyle pay sahiplerinin başlangıçta yatırım yaptıkları ortaklıktan farklı bir ortaklıkta kalmaya zorlanmamaları ve zarara uğramaksızın ortaklık ile ilişkilerine son verilmesi imkanı tanımaktadır. Bu doğrultuda, ayrılma hakkının önemli nitelikteki işlem gerçekleştirilmeden önceki aşamada, pay sahibine dürüst koşullar altında önemli nitelikteki işlemin sonucunun olumlu veya olumsuz olmasına, zarar doğurup doğurmamasına bakmaksızın yeni bir yatırım kararı verdirmeyi amaçladığı söylenebilir. ${ }^{10}$ Pay sahibine ayrılma hakkının tanınmasıyla birlikte, önemli nitelikte bir işleme karar verilmeden önce ayrılma hakkının yaratacağı maliyetin de dikkate alınması gerekecektir. Çünkü pay sahiplerini memnun etmeyecek önemli nitelikteki bir karar birçok pay sahibinin ayrılma hakkını kullanmasını tetikleyebilecek ve bu durum ortaklık açısından büyük bir maliyet getirebilecektir. Bu nedenle, ayrılma hakkının ortaklığın yönetimini elinde tutan pay sahiplerinin ortaklığın kötü yönetimine karşı bir kontrol vasıtası amacı güttüğünü ve yöneticilerin denetlenmesi amacına hizmet ettiğini söylemek de mümkündür. ${ }^{11}$

Ayrılma hakkının amacının doğru bir şekilde tespit edilebilmesi için bu hakkın doğuşunun ve tarihsel gelişiminin de incelenmesi gerekmektedir. Ayrılma hakkı Anglo Sakson ve Kita Avrupası hukuklarında 19. yy’ın ikinci yarısında ortaya çıkmıştır. ABD hukukunda 1870 'lerden önce anonim ortaklığın varlığı ortaklık, pay sahipleri ve devlet arasında yapılan bir şirket sözleşmesine dayanmaktaydı. ABD'deki birçok eyalette kabul edilen genel prensip, anonim ortaklığın pay sahiplerinin oybirliği olmaksızın başka bir anonim ortaklık ile birleşemeyeceği, ortaklık sözleşmesinin değiştirilemeyeceği ve ortaklığa ilişkin esaslı değişiklikler yapılamayacağı yönündeydi. ${ }^{12} 19$. yy’ın ikinci yarısında ekonominin canlanması, demiryolu projelerinin hayata geçirilmesi gibi

Ayşegül Özdoğan, "Halka Açık Anonim Ortaklıklarda Pay Sahibinin Ortaklıktan Ayrılma Hakkı", Cumhuriyetin 80. Yılına Armağan, 2. C, Ankara, Sermaye Piyasası Kurulu Yayınları, 2004, s. 707; Yusuf Sönmez, Anonim Ortaklıklarda Pay Sahibinin Ortaklıktan Ayrılma Hakkı, İstanbul, Beta Yayıncılık, 2009, s.1; SPK Gerekçesi, s. 26.

8 Manavgat, Halka Açık Anonim Ortaklıklar, s. 322; Adıgüzel, s. 5.

9 Barry M. Wertheimer, "The Shareholders' Appraisal Remedy And How Courts Determine Fair Value", Duke Law Journal, 47. C, 4. S, 1998, s. 614 vd; Hideki Kanda/ Saul Levmore, "The Appraisal Remedy and the Goals of Corporate Law”, University of California Los Angeles Law Review, 32. C, 1985, s. 434.

10 Özdoğan, s. 707; Manavgat, Halka Açık Anonim Ortaklıklar, s. 323.

11 Burak Adıgüzel, "Halka Açık Anonim Ortaklıklarda Pay Sahibinin Ayrılma Hakkı", GÜHFD, 18. C, 2. S, 2014, s. 5; Kraakman/Armour/Davies/Enriques/Hansmann/Hertig/Hopt/Kanda/Rock, s.201; Manavgat, Halka Açık Anonim Ortaklıklar, s. 321 vd; Kanda/Levmore, s. 443.

12 Wertheimer, s. 618. 
ekonomik ve teknolojik gelişmeler, ortaklıklar arasındaki rekabeti artırmış ve ortaklıklar daha fazla büyüyebilme arayışına girmişlerdir. Ancak, ortaklıkların büyüyebilmeleri için gerekli olan birleşme işlemleri için pay sahiplerinin oybirliği aranması kuralı, hızla büyümeye başlayan, sürat ve dinamizm gerektiren ticaret hayatının yapısına uymamaya başlamıştır. Bu husus Amerikan Mahkemelerinde de tartışılmıştır. Mahkemelerin ilk olarak, kamu yararının gerekli kıldığı hallerde şirket sözleşmesindeki hükümleri değiştirebileceği yönünde kararlar vermesiyle ortaklıklarda oybirliğiyle karar alınması kuralı delinmiş, daha sonra ortaklık için faydalı olabilecek ve çoğunluğun kabul ettiği bir işlemin yalnızca bir veya birkaç pay sahibinin veto hakkını kullanması nedeniyle engellenmesinin makul olmayacağına ve birleşmede aranan oybirliği kuralının karara karşı olumsuz oy kullanan pay sahiplerine payları karşılığı olan bedel verilerek ortaklıktan çıkarılmalarına hükmetmesi ile bu kuraldan uzaklaşılmaya ve ayrılma hakkı gündeme gelmeye başlamıştır. Bu gelişmeleri, mahkemelerin birleşme, şirket sözleşmesi değişikliği yanında ortaklığın mallarının satışı gibi çeşitli işlemler için de oyçokluğu prensibinin kabul edilebileceğine hükmetmesi takip etmiş ve nihayet ayrılma hakkı eyaletlerde kanuni düzenlemeye kavuşturulmuştur. ${ }^{13}$ Görüleceği üzere, ayrılma hakkı anonim ortaklıklarda oy birliği ilkesinden oy çokluğu ilkesine geçiş sürecinde ortaya çıkmıştır. ${ }^{14}$

Kıta Avrupası'nda ise ayrılma hakkı ilk olarak 1882 tarihli İtalya Krallı̆̆ Ticaret Kanunu'nda düzenlenmiş ve düzenlemede sermayenin tamamlanması veya artırılması, ortaklığın faaliyet konusunun değiştirilmesi, sürenin uzatılması veya başka ortaklıklarla birleşme kararına muhalefet eden ortaklara bu hak tanınmıştı. ${ }^{15}$

\subsection{Hukuki Niteliği}

SPK md. 24'te, ayrılma hakkının herhangi bir pay sahibi tarafindan kanunda belirtilen belirli şartların gerçekleşmesi halinde kullanılabileceği öngörülmüştür. Ayrılma hakkının kullanılabilmesi için pay sahibinin payının esas veya çıkarılmış sermayeye oranı önemli değildir. SPK md. 24/1-2'de öngörülen şartları yerine getiren her bir pay sahibi tek taraflı irade beyanıyla bu hakkını kullanabilir. Bu açıdan ayrılma hakkı bireysel bir hak niteliğindedir. Pay sahibi dışındaki tahvil, kira sertifikası gibi hisse senedi haricindeki menkul kıymet sahipleri, alacaklılar, ortaklığın çalışanları ve ortaklıkla ilgili diğer menfaat sahipleri, pay sahibi sıfatı sona ermiş veya pay sahipliği sıfatını kazanamamış kimseler bu hakkı kullanamazlar. ${ }^{16}$

SPK md. 24'te ayrılma hakkı genel kurula katılan ve önemli nitelikteki işleme ilişkin karara olumsuz oy kullanan ve muhalefetini toplantı tutanağına işleten pay sahipleri

\footnotetext{
13 Sönmez, s. 9-17; Özdoğan, s. 708, 709; Wertheimer, s. 618, 619.

14 Irving J. Levy, "Rights of Dissenting Shareholders to Appraisal and Payment", Cornell Law Review, 420. C, 1930, s. 420 vd; Bayless Manning, "The Shareholders's Appraisal Remedy: An Essay for Frank Coker”, The Yale Law Journal, 72. C, 2. S, 1962, s. 226; Sönmez, s. 19; böyle bir bağlantı kurmanın doğru olmadığı yönünde bknz. Kanda/Levmore, s. 430.

15 Sönmez, s. 17.

16 Manavgat, Halka Açık Anonim Ortaklıklar, s. 323; Adıgüzel, s. 6; Sönmez, s. 63; Özdoğan, s. 720, 721.
} 
tarafindan kullanılabileceği belirtildiğinden ayrılma hakkını kullanmak isteyen pay sahibinin oy hakkının bulunması gerekmektedir. Oy hakkının doğmadığı halde ve oydan yoksunluk halinde ${ }^{17}$ ayrılma hakkı kullanılamaz. ${ }^{18}$ SPK md. 29/6' da önemli nitelikteki işlemin onaylandığı genel kurulda bu işlemlere TTK md. 436/1'e göre taraf olan pay sahiplerinin oy kullanamayacakları belirtilmiştir. Ancak, Önemli İşlemler Tebliği md. 7/2 ve 3 'te ise SPK md. 29/6'dan daha farklı bir düzenleme yer almaktadır. Önemli İşlemler Tebliği md. 7/2'de önemli nitelikteki işlemin oylanacağı genel kurula, bu işlemlere TTK md. 436/1 anlamında taraf olan her pay sahibinin değil, sadece işlemlere taraf olan nihai kontrol eden ortak statüsündeki gerçek kişiler veya bunların yönetim kontrolüne ${ }^{19}$ sahip ortaklıkların bu işlemlerin gerçek kişilerin kendileri için doğrudan kişisel nitelikte sonuç doğurması halinde oy kullanamayacakları belirtilmiştir. Ayrıca, md. 7/3'te kişisel nitelikte sonuç doğurmadığı kabul edilen bazı işlemler gösterilmiştir. Kişisel sonuç doğurmadığı kabul edilen işlemler; i) Birleşme, bölünme işlemlerine tarafolma, tür değiştirme veya sona erme kararı alınması, ii) Faaliyet konusunun tümüyle veya önemli ölçüde değiştirilmesi ve iii) Borsa kotundan çıkma kararının alınmasıdır. Böylelikle, Önemli İşlemler Tebliği md. 7/2 ve 3 ile SPK md. 29/6' da yer alan düzenleme sınırlandırılmıştır. ${ }^{20}$

Ayrılma hakkı, kanunen düzenlenmiş bir hak olduğu için bu hakkın ana sözleşme hükmüyle veya pay sahibinin kendi iradesiyle sınırlanması veya kaldırılması mümkün değildir. $\mathrm{Bu}$ açıdan ayrılma hakkı vazgeçilmez nitelikte bir haktır. ${ }^{21} \mathrm{Bu}$ hakkın uygulanmasında eşit işlem ilkesi mutlak olarak uygulanır. Dolayısıyla bazı

17 TTK md. 434'e göre her pay, sahibine en az bir oy hakkı verir. Pay sahipleri, oy haklarını genel kurulda, paylarının toplam itibarî değeriyle orantılı olarak kullanır. Bu hükmün emredici olduğu ve TTK sisteminde oy hakkı bulunmayan pay oluşturulmasının mümkün olmadığı kabul edilmektedir. Bununla birlikte TTK'da pay sahibinin oy hakkının bulunmadığı bazı haller düzenlenmiştir: TTK md. 435'e göre oy hakkı, payın kanunen (yüzde yirmibeş) veya esas sözleşmeyle belirlenmiş bulunan en az miktarının ödenmesiyle doğar. Ayrıca, TTK md. 436' da iki oydan yoksunluk hali düzenlenmiştir. Maddeye göre, "pay sahibi kendisi, eși, alt ve üstsoyu veya bunların ortağı olduklarl șahıs șirketleri ya da hâkimiyetleri altındaki sermaye şirketleri ile şirket arasındaki kişisel nitelikte bir işe veya işleme veya herhangi bir yargı kurumu ya da hakemdeki davaya ilişkin olan müzakerelerde oy kullanamaz. Şirket yönetim kurulu üyeleriyle yönetimde görevli imza yetkisini haiz kişiler, yönetim kurulu üyelerinin ibra edilmelerine ilişkin kararlarda kendilerine ait paylardan doğan oy haklarını kullanamaz". Maddede belirtilen kișilerin alınacak kararlarla kișisel olarak ilgili olması oydan yoksunluğu doğurmaktadır. Maddede belirtilen hallerin oydan yoksunluğu gerektirmesinin sebebinin menfaat çatışması olduğu söylenebilir.

18 İbrahim Bektaș, "Halka Açık Anonim Ortaklıkların Önemli Nitelikteki İșlemleri Nedeniyle Doğan Ayrılma Hakkı ve Pay Alım Teklifi Zorunluluğu”, Banka ve Ticaret Hukuku Enstitüsü 60. Yıl Armağanı, Ankara, Bankacılık Enstitüsü Yayınları, 2015, s.806, 807; Derin Altan, "Sermaye Piyasasında Pay Sahiplerinin Ayrılma Hakkı ve Önemli Nitelikteki İşlemler", Banka ve Finans Hukuku Dergisi, 3. C, 11. S, 2014, s. 155; Özdoğan, s. 750 vd. Aksi yönde Adıgüzel, s. 34; Sönmez, s. 67. Yazarlara göre, ayrılma hakkının muhalefet etmeye bağlı bir hak olması, bu hakkın mutlak olarak oy hakkına sahip pay sahiplerince kullanılmasını gerektirmez. Bu doğrultuda, ayrılma hakkının kullanılabilmesi için genel kurula katılma hakkının varlığı gerekli ve yeterlidir. Oy hakkından yoksunluğun, genel kurula katılma ve bundan kaynaklanan görüş açıklama, bilgi alma gibi diğer yönetime katılma haklarına bir etkisi bulunmamaktadır. Bu nedenle, oy yoksunluk halinde ilgili pay sahiplerinin genel kurula katılma hakları bulunduğu ölçüde ayrılma hakkına sahip olduğunu kabul etmek gerekmektedir.

19 Önemli İşlemler Tebliği md. 4/1/k'ya yönetim kontrolü SPK md. 26'da tanımlanan kontrol gücüdür. SPK md. 26/2 ve 3'e göre"(2) Ortaklığın oy haklarının yüzde ellisinden fazlasına tek bașına veya birlikte hareket ettikleri kişilerle beraber, doğrudan veya dolaylı olarak sahip olunması, yönetim kurulu üye sayısının salt çoğunluğunu seçme veya genel kurulda söz konusu sayıdaki üyelikler için aday gösterme hakkını veren imtiyazlı paylara sahip olunması, yönetim kontrolünün elde edilmesi olarak kabul edilir. Ancak, imtiyazl payların mevcudiyeti nedeniyle yönetim kontrolünün elde edilemediği hâller bu madde kapsamında değerlendirilmez.

(3) Ortaklı̆̆ın pay sahipliğinde herhangi bir değişiklik olmasa bile, 23 üncü maddenin birinci fikrasında Kurulca belirlenmesi öngörülen usul ve esaslar ile 29 uncu maddenin altıncı fikrasındaki usul ve esaslara uyulmadan, bazı ortakların kendi aralarında yapacakları özel anlaşmalarla yönetim kontrolünü ele geçirmeleri de bu madde kapsaminda değerlendirilir."

20 Veliye Yanlı, "Halka Açık Şirketlerde Önemli Nitelikteki İşlemler”, IÜHFD, 6. C, 2. S, 2015, s. 466.

21 Adıgüzel, s. 6. Aksi yönde Manavgat, Halka Açık Anonim Ortaklıklar, s. 324. 
pay sahiplerinin bu hakka sahip olması, bazılarının sahip olmaması söz konusu olamaz. ${ }^{22}$ Bunun bir sonucu olarak, bu hakkın imtiyaza konu olması mümkün değildir. ${ }^{23}$ Ancak, ayrılma hakkının vazgeçilmez nitelikte olması, SPK md. 24 ve Önemli İşlemler Tebliği’nde belirtilen önemli işler gerçekleştikten sonra pay sahipleri tarafından tek taraflı olarak bu hakkın kullanılmasından vazgeçilmesi veya pay sahibi ile ortaklık arasında bir sözleşme düzenlenerek ayrılma hakkının kullanılmayacağının kararlaştırılmasına engel değildir. Çünkü, SPK'da öngörülen gerekli koşullar oluştuktan sonra pay sahibi ayrılma hakkını kullanıp kullanmamakta serbesttir ve bu hak üzerinde serbestçe tasarruf edebilir. ${ }^{24}$

Ayrılma hakkının kullanılması sonucunda pay sahibine bir miktar para verilmektedir. $\mathrm{Bu}$ açıdan ayrılma hakkı para ile ölçülebilen bir değere sahip olması nedeniyle bir malvarlıksal haktır. ${ }^{25}$

SPK md. 24/3 ve Önemli İşler Tebliği md. 9/4'te ortakllğın, genel kurul gündeminde pay sahiplerine paylarını satın alacağına ilişkin bir teklifte bulunması zorunlu tutulmuştur. Burada borçlar hukuku anlamında olmasa da kanun gereği sözleşme kurma zorunluluğu çerçevesinde zorunlu bir icabın varllğından bahsetmek gerekmektedir. ${ }^{26}$ Genel kurul gündemine yer alan payların ortaklık tarafından satın alınacağı ve payların birim bedellerine ilişkin bilgi icap, pay sahibinin ayrılma hakkını kullandığını ortaklığa bildirmesi kabul olarak değerlendirilmekte ve ayrılma hakkının kullanımının özünde bir alım satım sözleşmesi olduğu fikri ileri sürülmektedir. ${ }^{27}$ Ancak, söz konusu alım satım sözleşmesinin borçlar hukukundaki sözleşme serbestisi prensibi kapsamında değil, SPK gereğince kanunen sözleşme kurma zorunluluğu çerçevesinde kurulduğunun, bu kapsamında ortaklığın sözleşmenin içeriğini, karşı tarafını belirlemekte ve sözleşmeyi akdedip akdetmemekte serbest olmadığının vurgulanması gerekmektedir. ${ }^{28}$

Son olarak, ayrılma hakkı pay sahibinin tek taraflı irade beyanıyla karşı tarafın iradesinden bağımsız olarak bir hukuki ilişki (alım satım sözleşmesi) kurma özelliği göstermesi nedeniyle bir yenilik doğuran hak niteliğindedir. ${ }^{29} \mathrm{Bu}$ nedenle, ayrılma hakkının kullanılması şarta tabi tutulamaz ve sonuç meydana geldikten sonra bu haktan geri dönülemez. ${ }^{30}$

\footnotetext{
Ünal Tekinalp, Sermaye Ortaklıklarının Yeni Hukuku, 3. Bs., İstanbul, Vedat Kitapçılık, 2013, s. 301; Manavgat, Halka Açık Anonim Ortaklıklar, s. 323.

Adıg̈̈zel, s. 6; Sönmez, s. 74.

Manavgat, Halka Açık Anonim Ortaklıklar, s. 324.

Adıgüzel, s. 6; Sönmez, s. 76.

Bektaş, s. 762 .

Bektaş, s. 762; Adıgüzel, s. 38; Sönmez, s .141; Manavgat, Halka Açık Anonim Ortaklıklar, s. 328.

Bektaş, s. 763; Manavgat, Halka Açık Anonim Ortaklıklar, s. 328.

Bektaş, s. 767.

Kemal Oğuzman/Nami Barlas, Medeni Hukuk, İstanbul, Vedat Kitapçılık, 2015, s. 164, 165.
} 


\subsection{TTK Ve SPK'daki Benzer Düzenlemelerle Karşılaştırılması}

1.3.1 TTK'daki benzer düzenlemeler. TTK sisteminde bir anonim ortaklıktaki pay sahibinin tek taraflı irade beyanı ile ortaklıktan ayrılmasını mümkün kılan bir hak bulunmamaktadır. Bununla birlikte, pay sahibinin belirli şartlar dahilinde ortaklıktan fiili olarak ayrılmasını sonuçlayabilen düzenlemeler bulunmaktadır. Bu düzenlemeler, i) şirketler topluluğunda hakimiyetin kötüye kullanılması durumunda pay sahibinin mahkemeden paylarının satın alınmasını talep etmesi, ii) hakim şirketin belirli şartlar dahilinde azlığın paylarını satın alması, iii) şirket birleşmelerinde birleşme sözleşmesinde ayrılma akçesi öngörülmesi, iv) haklı neden fesih davasında davacı azınlığın mahkemece ortaklıktan çıkartılması ve v) 1skattır.

i) TTK md. 202/1'e göre, bir şirketler topluluğunda hakim ortaklığın hakimiyetini bağlı ortaklığı kayba uğratacak şekilde kullanması ve kaybın ilgili faaliyet yılı içinde denkleştirilmemesi veya bağlı ortaklığa denk bir istem hakkı tanınmaması durumunda bağlı ortaklığın her bir pay sahibi mahkemeye başvurarak ortaklığın zararının tazmin edilmesini talep edebilir. Hakim istem üzerine veya resen hakkaniyete uygun düşecek ise pay sahiplerinin paylarının hakim ortaklık tarafindan satın alınmasına veya duruma uygun düşen başka bir çözüme karar verebilir.

TTK md. 202/2'ye göre, hakim ortaklığın hakimiyet gücünü kullanarak bağl1 ortaklık için haklı bir sebebi olmayan birleşme, bölünme, tür değiştirme, fesih, menkul kıymet çıkarma ve önemli esas sözleşme değişiklikleri yapması durumunda, ilgili genel kurul kararı için olumsuz oy kullanıp muhalefetini tutanağa geçirten veya yönetim kurulunun yukarıda belirtilen nitelikteki kararlarına yazılı olarak itiraz pay sahipleri mahkemeden hakim ortaklığın paylarını satın almasını veya zararlarının tazmin edilmesini talep edebilirler.

Yukarıda izah edildiği üzere, TTK 202/2'deki düzenleme dayanağını ortaklık için alınan önemli nitelikteki işlemlere bağlaması yönünden SPK md. 24'te ayrılma hakkına benzemektedir. Ancak 202/1 ve 2'de öngörülen hükümler pay sahibine tek taraflı irade beyanı kullanabileceği bir hak olarak düzenlenmemiştir. İlgili pay sahibinin ortaklıktan ayrılabilmesi için dava açması ve mahkemenin pay sahibinin payının ortaklık tarafından satın alınması ve ortaklıktan ayrılmasına karar vermesi gerekir.

ii) TTK md. 208'e göre, bir şirketler topluluğunda hakim ortaklık doğrudan veya dolaylı olarak bir sermaye ortaklığının paylarının ve oy haklarının en az yüzde doksanına sahipse ve azlık ortaklığın çalışmasını engelliyor, dürüstlük kuralına aykırı davranıyor, fark edilir sıkıntı yaratıyor veya pervasızca hareket ediyorsa, hakim ortaklık azlığın paylarını satın alabilir. Bu hakkın mahkemeye başvurarak mı yoksa hakim ortaklığın tek taraflı irade beyanı ile mi kullanılacağı madde metninde açıkça düzenlenmemiştir. TTK md. 208'in gerekçesinde kararın mahkemeye bırakılmış olduğunun belirtilmesi ve madde metninde pay bedellerinin tespiti için 
TTK md. 202'ye atıf yapılmış olması nedeniyle bu hakkın mahkeme aracılığıyla kullanılabileceğini kabul etmek gerekir. ${ }^{31}$ TTK md. 208'deki satın alma hakkının belirli bir hakimiyet oranına sahip olan hakim ortaklıkça, bu hakkın yalnızca teknik anlamda azlığa karşı kullanılması ve bu hakkın kullanılabilmesi için mahkemeye başvurmanın gerekmesi sebebiyle SPK md.24'teki ayrılma hakkından önemli ölçüde farklı1ık içerdiğini söylemek mümkündür.

iii) TTK'da pay sahibinin ortaklıktan ayrılmasını sonuçlayan diğer bir husus TTK 141 gereğince şirket birleşmelerinde birleşme sözleşmesinde ayrılma akçesi öngörülmesidir. Düzenlemeye göre birleşmeye katılan ortaklıklar birleşme sözleşmesinde pay sahiplerine, devralan ortaklıkta pay sahibi olma veya ayrılma akçesi alarak ortaklıktan ayrılma hakkı arasında bir seçim hakkı tanıyabilir veya birleşme sözleşmesinde sadece ayrılma akçesinin verilmesini öngörebilirler. TTK md. 155/2'de düzenlenen kolaylaştırılmış birleşmeden farklı olarak, birleşme sözleşmesinde ayrılma akçesi öngörülmesi zorunlu değildir. Bu hakkın tanınması durumunda, ilgili pay sahibi tek taraflı irade beyanı ile ortaklıktan ayrılabilir. Ancak SPK md. 24'teki ayrılma hakkından farklı olarak bu hak yalnızca birleşme işlemleri ile sınırlı olmakla birlikte birleşme sözleşmesinde bu hakkın düzenlenmesine bağlıdır.

iv) TTK md. 531' e göre haklı sebeplerin varlığ 1 halinde, azlık pay sahipleri ortaklığın feshedilmesini mahkemeden talep edebilirler. Mahkeme, fesih yerine davacı pay sahiplerine paylarının karar tarihine en yakın tarihteki gerçek değerinin ödenip davacı pay sahiplerinin ortaklıktan çıkarılmalarına veya duruma uygun düşen başka bir çözüme karar verebilir. Bu düzenleme, yalnızca azlık için öngörülmüş olmas1 ve pay sahibinin ortaklıktan ayrılmasına mahkemece karar verilecek olmas1 nedeniyle ayrılma hakkından farklılaşmaktadır.

v) TTK'da 1skat sermaye koyma borcunu süresi içinde yerine getirmeyen pay sahipleri için öngörülmüştür. TTK md. 482'ye göre, yönetim kurulu sermaye koyma borcunda temerrüde düşen pay sahibinin payını satıp yerine başkasını almaya ve kendisine verilmiş pay senetlerini iptal etmeye yetkilidir. TTK kapsamında 1skat yönetim kuruluna tanınmış bir yetki olarak düzenlenmiştir ve kapsamı sadece sermaye koyma borcunun yerine getirilmemesine ilişkindir. Bu nedenle, ayrılma hakkının şartlarından ve ayrılma hakkının amacından önemli ölçüde farklıdır.

1.3.2 SPK'daki benzer düzenlemeler. Ayrılma hakkı dışında, SPK'da pay sahibinin ortaklıktan ayrılmasını sonuçlayan 2 düzenleme vardır. Bunlar i) pay alım teklifi yoluyla pay sahibinin payının teklif sahibi tarafından satın alınması ve ii) çıkarma ve satma haklarının kullanılmasıyla pay sahibinin ortaklıktan ayrılmasıdır.

i) Pay alım teklifi her bir pay sahibinin payının satın alınması için münferit işlem yapmak zorunda kalmaksızın tek tip bir çağrı yoluyla birçok pay sahibinin

\footnotetext{
31 İrfan Akın, “TTK M.208 Kapsamında Anonim Şirketlerde Azınlığın Ortaklıktan Çıkarılması”, GÜHFD, 17. C, S. 1-2, 2013 , s. 13.
} 
payının satın alınması için yapılan tekliftir. ${ }^{32}$ Pay alım teklifi SPK'da 3 farklı şekilde düzenlenmiştir. Bunlardan ilki SPK md. 25'te düzenlenen gönüllü pay alım teklifidir. Gönüllü pay alım teklifi, zorunlu teklif yapılmasını gerektiren bir durum olmaksızın ortaklığın paylarının tamamı veya bir kısmının teklif veren tarafından satın alınması için yapılan bir tekliftir. Gönüllü pay alım teklifi ve zorunlu pay alım teklifinde bulunulmasına ilişkin esaslar Pay Alım Teklifi Tebliği'nde düzenlenmiştir. Pay sahiplerinin teklifi kabul etmeleri durumunda ilgili paylar teklif sahibi tarafindan satın alınmakta ve pay sahibinin ortaklık ile ilişkisi son bulmaktadır.

SPK md. 25'te düzenlenen ikinci pay alım teklifi ise aşağıda 2. başlık altında incelendiği üzere bazı önemli nitelikteki işlemlerde işlemden yararlananlar tarafından pay alım teklifinde bulunulması zorunluluğu öngörülmüştür. Bu durumda ayrılma hakkının şartlarını yerine getiren pay sahibinin payı ortaklık tarafından değil işlemden yararlanan tarafindan satın alınmakta ve ilgili pay sahibi ortaklıktan ayrılmaktadır.

Pay alım teklifinin diğer görünümü SPK md. 26'da düzenlenen zorunlu pay alım teklifidir. Zorunlu pay teklifini doğuran temel sebep ortaklıkta yönetim kontrolünün el değiştirmesidir. İlgili maddeyle halka açık anonim ortaklığın yönetim kontrolünü sağlayan payların veya oy haklarının edinilmesi durumunda hakim ortağa diğer ortakların paylarını satın almak üzere teklifte bulunma zorunluluğu getirilmiştir. Yönetim kontrolü ise SPK md. 26/2'de ortaklığın oy haklarının en az \%50 veya daha fazlasına sahip olmak veya bu orana bağlı olmaksızın yönetim kurulunda hakimiyet hakkı veren imtiyazlı paylara sahip olmak olarak tanımlanmıştır.

Görüldüğü üzere SPK md. 26' da düzenlenen pay alım teklifinin yalnızca ortalıktaki kontrol değişikliği halinde uygulama alanı bulan bir düzenleme olması, buna rağmen aşağıda 2. başlık altında incelendiği üzere ayrılma hakkını sonuçlayan önemli nitelikteki işlemlerin çok daha kapsamlı olması ve Kurul'un, SPK veya Önemli Nitelikteki İşlemler Tebliğinde önemli nitelikteki işlem olarak düzenlenmeyen işlemleri de önemli olarak değerlendirme yetkisi bulunması nedeniyle pay sahiplerine daha sınırlı bir koruma sağladığını söylemek mümkündür.

ii) Halka açık anonim ortaklıkta pay sahibinin ortaklıktan ayrılmasını sonuçlayan diğer bir düzenleme SPK md. 27'deki çıkarma ve satma haklarıdır. Çıkarma hakk1, pay alım teklifi sonrasında veya başka bir şekilde belirli bir pay oranına ulaşan pay sahibinin azınlıkta kalan pay sahiplerini ortaklıktan çıkartma hakkı olarak tanımlanabilir. ${ }^{33} \mathrm{Bu}$ oran Çıkarma ve Satma Hakları Tebliği md. 4'te \% 98 olarak belirtilmiştir. $\mathrm{Bu}$ doğrultuda, ortaklıktaki pay oranı \%98'e ulaşan hakim ortak, bu hakkını ortaklığa yazılı bir bildirimde bulunmak suretiyle kullanabilir. Bu hakkın

\footnotetext{
32 Manavgat, Halka Açık Anonim Ortaklıklar, s. 355.

33 Salih Önder Yeşiltepe, Halka Açık Anonim Ortaklıklarda Çıkarma ve Satma Hakları, 2. Bs., Ankara, Seçkin Yayıncilik, 2015, s. 53.
} 
kullanılmas1 sonucunda pay oran $\% 2$ veya daha az olan pay sahibi ortaklıktan çıkarılmakta ve paylarına karşılık ortaklık tarafından çıkarılan yeni paylar hakim ortağa devredilmektedir. Ortaklıktan çıkarılan pay sahiplerine satım bedeli doğrudan hakim ortak tarafından değil, ortaklık tarafından ödenmektedir. Ancak, Çıkarma ve Satma Hakları Tebliği md. 5/8'e göre, satım bedeli hakim ortağın kendisi için yapılan tahsisli sermaye artışı sebebiyle yapacağı ödemeden karşılanır.

Satma hakkı ise çıarma hakkının diğer bir görünümüdür. Satma hakk1, çıkarma hakkının doğduğu durumlarda \% 2 veya daha çok küçük orandaki pay sahibinin kendi paylarının hakim ortak tarafından satın alınmasını talep etme hakkı olarak tanımlanabilir. ${ }^{34}$

Satma ve çıkarma hakları yukarıda açıklandığı üzere ancak halka açık anonim ortaklıktaki hâkimiyet oranının belirli bir yüzdeye ulaşması durumunda kullanılabilen haklardır. Bu nedenle kapsamının, doğuşu ortaklıkça alınan önemli nitelikteki genel kurul kararlarına bağlı olan ayrılma hakkından daha sınırlı olduğunu söylemek mümkündür.

\section{Ayrılma Hakkının Şartları}

Ayrılma hakkının kullanılabilmesi için i) SPK md. 23 veya Önemli İşlemler Tebliği md. 5'te belirtilen veya Kurul tarafından önemli nitelikte işlem olarak değerlendirilen bir işlem olması, ii) bu hakkı kullanmak isteyen kişinin halka açık anonim ortaklıkta pay sahibi olmas1, iii) pay sahibinin SPK md. 24/1'de belirtilen şartları yerine getirmesi veya SPK md. 24/2'de belirtilen bir durumla karşılaşması gerekir. Birinci ve ikinci şartlar ayrılma hakkının kullanılması için maddi şartlardır. $\mathrm{Bu}$ şartların yanında, ayrılma hakkını kullanmak isteyen pay sahibinin bu hakkını dürüstlük kuralına uygun kullanması veya bu kararının haklı bir sebebe dayanması ya da önemli nitelikteki işleme onay veren pay sahiplerinin pervasızca bir tutum izlemesi gibi şartlar aranmamaktadır. Üçüncü şart ise ayrılma hakkının kullanım usulüne ilişkindir ve şekli bir şart niteliğindedir. ${ }^{35}$

\section{1 Önemli Nitelikteki İşlemler}

Türk Hukukunda halka açık anonim ortaklıkta pay sahibine ayrılma hakkı veren önemli nitelikteki işlemlerin sınırı SPK'da çizilmiş ancak bu işlemlerden ne anlaşılması gerektiğine ilişkin bir tanım yapılmamıştır. Bunun yerine, önemli nitelikte işlem özelliği gösteren bazı işlemler SPK md. 23'te sınırlı sayı ilkesine tabi olmamak üzere sayılmış ve önemli nitelikteki işlemlerin kapsamının belirlenmesi konusunda Kurul'a yetki verilmiştir. Ancak Kurul'un SPK'da sayılmayan bir işlemi önemli nitelikteki işlem rejimine tabi tutabilmesi için söz konusu işlemin Önemli İşlemler Tebliği md. 5/2'de belirtilen şartlara sahip olması gerekir. Önemli İşlemler Tebliği

\footnotetext{
4 Yeşiltepe, s. 10,55,56.

35 Bektaş, s 802; Adıgüzel, s. 32.
} 
md. 5/2'ye göre Kurul'un takdir yetkisini kullanarak bir işlemi önemli nitelikte bir işlem olarak değerlendirebilmesi için i) ortaklığın halka açılmadan önceki pozisyonu ile halka açıldıktan sonraki pozisyonunu önemli ölçüde değiştiren bir genel kurul kararı olması, veya ii) ortaklık halka açık iken faaliyetleri ve/veya ticari hayatında önemli ölçüde değişiklik meydana getiren bir karar olması gerekmektedir. İlgili hükümde halka arz sonrası döneme ilişkin bir sınırlama getirilmemiştir. Halka arzda kamuya açıklanmakla birlikte zaman içinde değişen koşullarla birlikte vaad ve taahütlerin gerçekleşmemesi, ortaklığın hukuki ve finansal yapısının değişmesi mümkündür. Bu kapsamda, hukukun ve zamanın değişimine göre Kurul'un önemli nitelikte işlemlerin sayısını artırabilmesi mümkün görülmüşken, bu yetki sınırsız olarak verilmemiş belirli koşullara tabi tutulmuştur. ${ }^{36}$

Örneğin SPK halka açık bir anonim ortaklığın sermayesinin tamamının geçmiş y1l zararlarına mahsup edilmesi için sermaye azaltımı yapılması ve eş zamanlı olarak sermaye artımı yapılması suretiyle paylarının halka arz edilmesinin planlandığ 1 izahnamenin onaylanması için kendisine yapılan bir başvuruda ${ }^{37}$, ortaklığın 2013 yılında gerçekleştirdiği ilişkili taraflardan iştirak edinimi işlemlerinin ortaklığın piyasa değerinin iki katından fazla bir tutarda olması ve ortaklığın halka açıklık oranının \%90 civarında olmasını dikkate alarak sermaye azaltımı ve artırımı nedeniyle yapılacak esas sözleşme değişikliği ile 2013 yılında gerçekleştirilen ilişkili taraflardan iştirak edinimi işlemlerinin görüşüleceği genel kurul toplantısına katılıp, olumsuz oy kullanacak ve muhalefet şerhini toplantı tutanağına işletecek pay sahiplerine SPKn'nun 24'üncü maddesi hükmü uyarınca ayrılma hakkı tanınması gerektiğine karar vermiştir.

SPK ve Önemli İşlemler Tebliği'nde sayılmayan ve Kurul'un da önemli nitelikte saymadığı bir işlemin ortaklık için önemi ne kadar büyük olursa olsun ayrılma hakkı kapsamında önemli nitelikte işlem sayılması mümkün değildir. ${ }^{38}$

Bir işlemin önemli nitelikte bir işlem sayılabilmesi için bir kısmının Önemli İşlemler Tebliği md. 5 kapsamına girmesi doğrudan yeterli sayılmakta, bir kısmının ise ayrıca md. 6'daki önemlilik kriterlerini sağlaması gerekmektedir. Madde 6'daki önemlilik kriterleri incelendiğinde ortaklığa parasal etkisi ölçülebilir işlemler için parasal önem ölçütleri ve ortaklığın faaliyet konusunun değiştirilmesi ile ilgili ölçütlerin getirildiği görülmektedir. ${ }^{39}$ SPK' da ve Önemli İşlemler Tebliği’nnde ayrılma hakkının ne zaman doğacağı açıkça düzenlenmemiştir. Ancak SPK md. 23 ve Önemli İşlemler Tebliği md. 9 ve 12'nin lafzı incelendiğinde ayrılma hakkını doğuran sebebin önemli

36 Bektaş, s. 770 vd.; Adıgüzel, s. 30; Manavgat, Halka Açık Anonim Ortaklıklar, s. 312.

37 Kurul'un 15.05.2013 tarihli, 2013/16 sayılı Haftalık Bülteni, http://www.spk.gov.tr/apps/haftalikbulten/displaybulten.aspx ?yil=2013\&sayi=16\&submenuheader=null, (Çevrimiçi), 9 Ocak 2017.

38 Bektaş, s.770 vd.; Adıgüzel, s. 30; Manavgat, Halka Açık Anonim Ortaklıklar, s. 312.

39 Yanlı, s. 461; Manavgat, Halka Açık Anonim Ortaklıklar, s. 295. 
nitelikteki işlem olduğunu söylemek mümkündür. $\mathrm{Bu}$ doğrultuda, önemli nitelikteki işlemin genel kurulca kabul edildiği anda ayrılma hakkının doğduğunu söylemek amaca uygun düşecektir. Ayrılma hakkının diğer şartları olan pay sahibinin önemli nitelikte işlemin görüşüldüğü genel kurul toplantısına katılması, ilgili işlem için olumsuz oy kullanması ve muhalefetini toplantı tutanağına işletmesi Önemli İşlemler Tebliği md. 9'da belirtildiği üzere ayrılma hakkının kullanım şartlarına ilişkindir ve doğrudan ayrılma hakkının doğması ile ilgili sayılmaz.

SPK md. 23'te düzenlenen önemli nitelikteki işlemler incelendiğinde bu işlemlerin bir kısmının yönetim kurulu tarafından alınabilecek kararlar olduğu görülmektedir. Ancak, böyle olsa dahi söz konusu karar SPK kapsamında önemli nitelikte bir işlem olduğu için genel kurulun onayına sunulması gerekmektedir. SPK md. 29/6 ve Önemli İşlemler Tebliği md. 7’te de açıkça ortaklığın önemli nitelikteki işlemlerinin genel kurul onayına sunulacağı belirtilmiştir.

Ayrılma hakkını doğuran önemli nitelikteki işlemlerin hemen hemen her biri kuşkusuz ayrı bir makale konusu olabilecek niteliktedir. Çalışmamızın ana konusunun ayrılma hakkı olması sebebiyle ayrılma hakkını doğuran önemli nitelikteki işlemlere çalışmamızda kısaca değinmeyi tercih ediyoruz.

\subsubsection{Birleşme, bölünme, tür değiştirme ve sona erme.}

2.1.1.1 Birleşme. SPK'da ayrılma hakkı veren birleşme TTK 136 kapsamındaki teknik ve hukuki anlamda birleşmedir. ${ }^{40}$ Birleşme işlemi, ortaklığın yapısında değişiklik yaratan, hatta devralınan ortaklığın pay sahibinin devralan ortaklığın pay sahibi olmasını ve dolayısıyla işlem temelinin değişmesini sonuçlayan bir işlemdir. $\mathrm{Bu}$ nedenle, birleşme işleminde pay sahiplerine ayrılma hakkı tanınması, ayrılma hakkının amacına uymaktadır. ${ }^{41}$

TTK md. 136 anlamındaki birleşme haricinde, ortaklıkların tüzel kişiliklerini kaybetmeksizin bir işe yönelik iş birliği yapmaları, bir ortaklığın diğer bir ortaklığın kontrolünü ele geçirmek amacıyla pay devri yapılması veya esas sözleşme değişikliği ile sermaye artırımına gidilmesi veya imtiyazlı pay tesis edilmesi ya da intifa hakkı tesis edilmesi gibi işlemler ${ }^{42}$ veya bir ortaklığın malvarlığının diğer ortaklık tarafından devralınmasıyla devreden şirketin feshedilmesi teknik anlamda birleşme sayılmaz ve ayrılma hakkının kullanılmasını sonuçlamaz. ${ }^{43}$

\footnotetext{
Çağlar Manavgat, "Türk Ticaret Kanunu Hükümlerinin Halka Açık Anonim Ortaklıklara Uygulanması Ve Sınırları”, İ̈HFM, 71. C, 2. S, 2013, s. 293.

41 Sönmez, s.93; Çetin/Töremiş/Cantimur, s. 68.

42 Ali Paslı, Anonim Ortaklığın Devralınması, Vedat Kitapçılık, İstanbul, 2009, s. 159-176, 202, 227, 232, 243.

43 Adıgüzel, s. 10; Sönmez, s.92.
} 
2.1.1.1.1 pay alım teklifi zorunluluğu öngören birleşme işlemleri. Pay sahibine ayrılma hakkı tanıyan önemli nitelikteki bir işlem olan birleşme işlemi ile birlikte ayrılma hakk1 doğurmayan, gerçekleştiğinde pay sahibine karşı pay alım teklifi yapılmasını zorunlu kılan iki tür birleşme işleminden de bahsedilmesi gerekmektedir. Bunlardan biri, Birleşme ve Bölünme Tebliği md. 4 ve Önemli İşlemler Tebliği md. 4/a'da öngörülen birleşme amaçlı ortaklıktır.

Birleşme amaçlı ortaklığın orijinal isminden ${ }^{44}$ de anlaşılacağı gibi bu ortaklıklar belirli bir amacı gerçekleştirmek için kurulmakta ve bu amacı gerçekleştirmek haricinde başka bir faaliyeti bulunmamaktadır. ${ }^{45} \mathrm{Bu}$ amaç önceden belirlenmiş bir süre içerisinde halka kapalı bir ortaklıkla birleşmektir. Birleşme amaçlı ortaklığın halka kapalı bir ortaklıkla birleşme işleminin onaylanması aşamasında genel kurul toplantısında söz konusu işlem için olumsuz oy kullanan pay sahipleri bulunursa bu pay sahiplerine veya birleşme amaçlı ortalık sona ererse kurucular dışındaki tüm pay sahiplerine gönüllü geri alım işlemi yapılmak zorundadır. Tebliğ'de her ne kadar gönüllü geri alım işleminden bahsedilse de gönüllü ifadesiyle pay sahiplerinin paylarını ortaklığa satıp satmamakta serbest oldukları kastedilmekte ve ortaklığın payları geri alım teklifi yapmasının zorunlu olduğu kabul edilmektedir. ${ }^{46}$

Zorunlu pay alım teklifi sonucunu doğuran diğer birleşme işlemi ise Önemli İşlemler Tebliği md. 11/1'de düzenlenmiştir. Md. 11/1 gereğince pay alım teklifi zorunluluğunun doğması için i) devrolunan ortaklığın bir borsa ortaklığı olması ve devralan ortaklığın paylarının borsada işlem görmemesi ve ayrıca ii) devralan ortaklığın birleşmeye esas olan finansal tabloları itibariyle aktif toplamının, payları borsada işlem gören devrolunan ortaklıktan daha büyük olması gerekmektedir. Paylarının borsada işlem görmediği ortaklıktan anlaşılması gereken ise halka kapalı ortaklıklar ile halka açık olmakla birlikte payları borsada işlem görmeyen ortaklıklardır. ${ }^{47}$

2.1.1.2 Bölünme. Bölünme, bir ticaret ortaklığının malvarlığının kısmen veya tamamen tasfiye edilmeksizin mevcut veya yeni kurulan en az iki ortaklığa külli halefiyet yoluyla ayni sermaye olarak devredilmesi olarak tanımlanabilir. ${ }^{48}$ Bölünmede ayrılma hakkının tanınmasının nedeni, bölünmenin birleşmede olduğu gibi pay sahiplerinin menfaatlerinde getirdiği büyük değişikliklerdir. Örneğin, halka açık ortaklığın tam bölünmesi sonucunda pay sahipliği haklarının sonlanması, kısmi bölünmede ise bölünme sonrası malvarlığını devralan şirketin halka açık olmaması hakların farklılaşmasına neden olmaktadır. Pay sahibinin ayrılma hakkı hem tam ve kısmi bölünme halinde mevcuttur. ${ }^{49}$

\footnotetext{
44 İlk olarak A.B.D.'de ortaya çıkan bu ortaklıklara special purpose acquisition company adı verilmektedir. Bkz. Gül Okutan Nilsson, Sermaye Piyasası Hukukunda Birleşme Amaçlı Ortaklık, Onİki Levha Yayıncılık, İstanbul, 2016, s. 18, $28,29$.

45 Derin Altan/Nil Acar, "Yeni Bir Alternatif Yatırım Aracı: Birleşme Amaçlı Ortaklıklar", Dokuz Eylül Üniversitesi Hukuk Fakültesi Dergisi, 16. C, 1. S, 2014, s. 253, 254; Bektaş, s. 777.

46 Bektaş, s. 777; Adıgüzel, s. 10.

47 Bektaş, s. 800.

48 Bilgili/Demirkapı, s. 93, 94; Hülya Coștan, Anonim Ortaklıklarda Bölünme, Turhan Kitabevi, Ankara, 2004, s. 23; Mustafa Çeker, "Ticaret Şirketlerinin Genel Hükümleri Ve Yeniden Yapılandırılmaları", EÜHFD, s. 117.

49 Adıgüzel, s. 12, 13, 14; Sönmez, s. 99.
} 
1.1.1.2 Tür Değisştirme. Tür değiştirme, bir ticaret ortaklığının malvarlığında herhangi bir değişiklik olmaksızın veya devredilmeksizin, ekonomik bütünlüğünün ve pay sahiplerinin payları korunarak başka bir hukuki şekle dönüşmesidir. ${ }^{50}$ TTK md. 181'e göre bir sermaye ortaklığı olan halka açık anonim ortaklık ancak limited ortaklık veya sermayesi paylara bölünmüş komandit ortaklığa ya da kooperatife dönüşebilir. Halka açık anonim ortaklığın tür değiştirme sonucunda dönüşebileceği ortaklıklar halka açık anonim ortaklığın yapısından, payların devir şekli ve pay sahibinin sorumluluğu açısından önemli farklılıklar içermekte, bu nedenle ayrılma hakkının kullanılmasını haklı kılmaktadır. ${ }^{51}$

1.1.1.3 Sona erme. Halka açık anonim ortaklığın sona ermesi tüzel kişiliğinin sona ermesi değil, faaliyetlerinin ve dolayısıyla kazanç elde etmenin durması veya durdurulması anlamına gelmektedir. ${ }^{52}$ Ortaklığın tüzel kişiliği tasfiye sonucunda sona ermektedir. TTK'ya göre, ortaklığın tüzel kişiliğinin sona ermesi fesih ve infisah hallerinin çıkması ile başlar, tasfiye işlemleri ile devam eder ve ticaret sicilden terkin işlemi ile tamamlanır. İnfisah, kanunda öngörülen ya da ana sözleşmede kararlaştırılan bir nedeninin gerçekleşmesi halinde, ortaklığın, bu yönde karar alınmasına veya bir ihbarda bulunulmasına gerek olmaksızın kendiliğinden sona ermesi halidir. Fesih ise genel kurul kararıyla ya da pay sahipleri, ortaklık alacaklıları veya Gümrük ve Ticaret Bakanlığı tarafından talepte bulunulması halinde mahkeme tarafindan anonim şirketin varlığının sona erdirilmesidir. ${ }^{53}$

Ayrılma hakkı, sadece genel kurul kararı ile gerçekleşen sona erme halinde pay sahibince şirkete karşı kullanabilecektir. Bu ihtimalde ayrılma hakkını, sona ermeyi kabul etmeyen pay sahibi kullanılabilecektir. ${ }^{54}$

\footnotetext{
50 Tekinalp, s. 675; Bilgili/Demirkapı, s. 108, 109.

Adıg̈̈zel, s. 14.

Tekinalp, s. 191.

3 Bilgili/Demirkapı, s. 565, 568; Mehmet Emin Bilgi, “Anonim Şirketin Sona Ermesi ve Tasfiyesi”, EÜHFD, 16. C, 3-4. S, 2012, s. 262, 263.

54 Adıgüzel, s. 15.
} 


\subsubsection{Ortaklığın önemli ölçüde malvarlı̆ğını devretme, üzerinde ayni hak tesis} etme veya kiralama. Malvarlığının ${ }^{55}$ tümünün veya önemli bir bölümünün devri ortaklık yeniden yapılandırılması anlamına gelmektedir. Ortaklığın sahip olduğu malvarlığının tümünün veya önemli bir bölümünün devredilmesiyle, ortaklık devre konu malvarlığından faydalanma hakkını kaybetmektedir. Bu işlem sonunda ortaklığın esas sözleşmesindeki iştigal konusu çerçevesinde faaliyet göstermesi imkanını yitirmesi halinde işletme konusunu gerçekleştirememesi nedeniyle sona erme sebebi gerçekleşebilir ve tasfiye sürecine girebilir. ${ }^{56}$ Ayrıca, malvarlığının devri bazı durumlarda ortaklığın kontrolünün devrini de sonuçlayabilir. ${ }^{57} \mathrm{Bu}$ nedenle, malvarlığının önemli bir bölümünün veya tamamının devri önemli nitelikteki bir işlem olarak görülmüştür. TTK 408/2/f'ye göre önemli miktarda ortaklık varlığının toptan satış1 genel kurulun karar verebileceği bir işlemdir. Bu nedenle, ortaklığın malvarlığının tümünün veya önemli bir bölümünün devrine genel kurulca karar verilmelidir. ${ }^{58}$

Benzer şekilde ortaklığın menkul veya gayrimenkul malvarlığı üzerinde sinırlı bir ayni hak tesis edilmesi SPK md. 23'e göre önemli nitelikteki işlem sayılmıştır. Önemli İşlemler Tebliği md. 6/1'de malvarlığının önemli bir bölümünün devrinden ne anlaşılması gerektiğine ilişkin bazı kriterler getirilmiş olup bu kriterlerin ortaklığının mal varlığını devretmesi, kiralaması veya üzerinde ayni hak tesis etmesi hallerinin her biri için sağlanması gerekmektedir. ${ }^{59}$

\subsubsection{1 İlişkili taraflardan önemli ölçüde malvarlığı edinme veya kiralama.} İlişkili taraflardan önemli ölçüde malvarlığı edinme veya kiralama Önemli İşlemler Tebliği md. 5/1/e> de düzenlenmiştir. Önemli İşlemler Tebliği md. 3/1/e'de ise ilişkili taraf, Türkiye Muhasebe Standartlarından tanımlanan ilişkili taraf olarak belirtilmiş, İlişkili Taraf Tebliği'nin ekinde bulunan standartlarda ise ilişkili taraf kişi ve işletmeler üzerinden detaylı bir şekilde tanımlanmıştır.

İlişkili taraf ile yapılan önemli ölçüde malvarlı̆ğ edinimi veya kiralama işleminin önemli nitelikteki işlem sayılabilmesi için Önemli İşlemler Tebliği md. 6/2-p ’ye göre işlem tutarının ortaklığın varlık toplamına veya borsa fiyatlarına göre hesaplanan değerine oranının \%50'yi aşması gerekir. Kiralama işlemlerinde ise varlığın kullanım ömrü dikkate alınarak kira tutarlarının indirgenmiş nakit akışı yöntemine göre hesaplanan net bugünkü değeri dikkate alınarak işlemin önemli olup olmadığına karar verilecektir.

\footnotetext{
55 Malvarlı̆̆ı bir kişinin para ile ölçülebilen hak ve borçlarının tümüdür. Malvarlığının aktif kısmında haklar pasif kısmında ise borçlar bulunmaktadır. Varlık sadece aktiflerden oluştuğu halde, malvarlığı aktif ve pasiflerden oluşmaktadır. Bknz. Levent Biçer/Esra Hamamcıoğlu, "Anonim Ortaklıklarda Genel Kurulun Devredilemez Yetkileri Kapsamında Önemli Miktarda Şirket Varlığının Toptan Satışı ve Uygulama Alanı”, KHÜHFD, 1. C, 1. S, 2013, s. 40; Mehmet Özdamar, "Anonim Ortaklığın Sahip Olduğu Malvarlığının Yönetim Kurulu Tarafından Topluca Devredilmesi”, SÜHFD, 14.c, 2.s, 2006, s.104.

56 Adıgüzel, s. 17; Sönmez, s. 105; Çetin/Töremiş/Cantimur, s. 68.

57 Bir ortaklığın malvarlığında bulunan başka bir ortaklığın çoğunluk paylarının mülkiyetinin diğer bir ortaklığa devredilmesi halinde ortaklığın kontrolünün de devredildiğinden bahsedilebilinecektir. Bknz. Paslı, s. 186, 187.

58 Manavgat, Halka Açık Anonim Ortaklıklar, s . 300; Bektaş, s. 784.

59 Bektaş, s. 785.
} 
Söz konusu düzenlemedeki amaç ortaklığın malvarlığını azaltabilecek nitelikteki işlemler olduğundan karşılıksız edinmelerin kapsam dışında bırakılması gerekir. ${ }^{60}$

2.1.3 Faaliyet konusunu değiştirme. Faaliyet konusunun ${ }^{61}$ tümüyle veya önemli ölçüde değiştirilmesi SPK md. 23'te önemli nitelikteki bir işlem olarak sayılmıştır. Ortaklığın faaliyet konusu yatırımcıların yatırım kararı verirken değerlendirdikleri bir husus olmakla birlikte şirketin karlılığını da etkilemektedir. Bu nedenle ortaklığın faaliyet konusunun tümüyle veya önemli ölçüde değiştirilmesi ayrılma hakkının kullanılması sonucuna bağlanmıştır. ${ }^{62}$

Ancak, Önemli İşlemler Tebliği md. 6/4'te faaliyet konusu değişikliğinin önemli sayılabilmesi için bazı ek koşullar getirilmiştir. Bu kapsamda söz konusu işlemin önemli sayılabilmesi için i) ortaklığın esas sözleşmesinde yer alan fiili ana faaliyet konusunun yan faaliyet haline gelmesine sebebiyet veren bir esas sözleşme değişikliği olması ya da ii) ortaklığın fiili ana faaliyet konusunu oluşturan mal ve hizmet üretiminin işleyiş sürecini değiştirecek nitelikte, örneğin üretim faaliyetinin tümüyle terk edilerek üretim konusu malın dışarıdan tedarik edilmesi gibi işlemler olması gerektiği düzenlenmiştir. Bu kapsamda, birinci koşulun gerçekleşmesi için ana sözleşme değişikliğinden sonra önceki faaliyet konusunun göreceli olarak önemini yitirip yitirmediğinin incelenmesi gerekir. ${ }^{63}$ Tebliğde ikinci koşulun gerçekleşmesi için esas sözleşme değişikliği gerekmez, bu tür işlemler TTK' ya göre yönetim kurulu kararı ile de yapılabilir. Ancak, söz konusu işlem SPK md. 23’te önemli nitelikteki işlem olarak sayıldığından genel kurulun görev alanına girmektedir. Bu nedenle yönetim kurulu tarafından alınan önemli nitelikteki işleme ilişkin kararın genel kurulun onayına sunulması zorunludur. ${ }^{64}$

\footnotetext{
60 Manavgat, Halka Açık Anonim Ortaklıklar, s. 307.

${ }_{61}$ TTK'da faaliyet konusunun tanımı bulunmamakta ve faaliyet konusu terimi yalnızca TTK md. 1523/2/b'de geçmektedir. Bununla birlikte, TTK'da işletme konusu terimi birçok yerde kullanılmış ve TTK md. 339'da anonim ortaklıklara esas sözleşmelerinde işletme konularını belirtme zorunluluğu getirilmiştir. İşletme konusu ortaklığın faaliyet alanını ifade etmek üzere kullanılmakta ve ortaklığın amacına ulaşması için yürütülen faaliyetleri ifade etmektedir. (Sevilay Uzunallı, Anonim Şirkette İşletme Konusu, Ankara, Adalet Yayınevi, 2013, s. 5,6,8.)

62 Çetin/Töremiş/Cantimur, s. 69.

63 Manavgat, Halka Açık Anonim Ortaklıklar, s. 303.

64 Bektaş, s. 789; Adıgüzel, s. 22.
} 


\subsection{4 İmtiyaz öngörme veya mevcut imtiyazların kapsam ve konusunu} değiştirme. Sermaye ortaklıklarında paylar arasında eşitlik ilkesinin istisnalarından birisi, imtiyazlı paydır. İmtiyaz, paya tanınan üstün bir hak olarak tanımlanabilir. ${ }^{65}$ Sermayenin tabana yayılması ilkesinin hakim olduğu ve bireylerin tasarruflarını büyük ortaklıklara sermaye olarak getirerek pay sahibi olmalarının amaçlandığı sermaye piyasası hukukunda yeni imtiyaz öngörülmesi veya mevcut imtiyazların içeriğinin değiştirilmesi yatırımcılar için önemli nitelikte bir işlem olarak görülmelidir. ${ }^{66}$

Ortaklıkta yeni bir imtiyaz yaratılması veya mevcut imtiyazlı grubun haklarının kapsamının genişletilmesi durumunda ayrılma hakkının gündeme gelebileceği söylenebilecek olmakla birlikte Önemli İşlemler Tebliği md. 11/1'e göre yeni bir imtiyaz öngörülmesi veya imtiyazların kapsamının değiştirilmesi durumunda işlemden yararlanacak taraf için pay alım teklifi zorunluluğu öngörüldüğünden, böyle bir durumda ilgili pay sahipleri ayrılma hakkını kullanamayacak, bunun yerine tebliğde belirtilen bedel üzerinden pay alım teklifinde bulunan tarafın teklifini kabul ederek ortaklıktan ayrılabilecektir. ${ }^{67}$ Ayrıca, mevcut bir imtiyazın kapsamının daraltılması söz konusu olduğunda bu durum diğer pay sahipleri lehine olduğu için bu pay sahiplerinin ayrılma hakkını kullanamaması gerekir. ${ }^{68}$

2.1.5 Borsa kotunda çıkma. Borsa kotuna alınma, sermaye piyasası araçlarının mevzuatta öngörülen şartları taşıması durumunda resmi borsa listesine kabul edilmesidir. ${ }^{69}$ Borsa kotundan çıkma ise ihraççının talebi üzerine veya başka bir yolla borsa otoritesinin kararıyla bir menkul kıymetin borsa kotasyonunun sona erdirilmesi, yani borsa listesinden çıkmasıdır. ${ }^{70}$ Ayrılma hakkının bir sebebini oluşturan SPK md. 23'te bir önemli nitelikteki işlem olarak düzenlenen kottan çıkma ise sadece payların borsa kotundan çıkarılmasını ifade eder. ${ }^{71}$ Borsa kotunda çıkma, payların devir kabiliyetini ve payların paraya çevrilebilme özelliğini sınırlandırdığı gibi, ortaklığın kamuyu aydınlatma ve kurumsal yönetim ilkelerine uyma gibi bir takım yükümlülüklerinin ve borsa otoritesinin denetiminin kalkmasına ve ortaklı̆ğı itibar kaybetmesi nedeniyle değerinin azalmasına neden olacağı için pay sahipleri açısından önemli sonuçlar doğurur. ${ }^{72}$

Borsa Kotasyon Yönetmeliği'ne göre bir ortaklık borsa kotundan kendi talebiyle çıkabileceği gibi yönetmelikte öngörülen belirli şartların varlığı halinde Borsa İstanbul A.Ş. Yönetim Kurulu tarafından da çıkarılabilir. Ayrılma hakkının söz

\footnotetext{
Hasan Pulaşlı, "Yeni Türk Ticaret Kanunu'na Göre Anonim Şirkette İmtiyazlı Paylar”, (Çevrimiçi) http://www.kazanci. com/kho2/hebb/files/dsp.php?fn=makale-hasanpulasli-1.htm\&kw=“imtiyaz`\#fm, 5 Ocak 2017.

Çetin/Töremiş/Cantimur, s. 69.

Manavgat, Halka Açık Anonim Ortaklıklar, s. 305; Bektaş, s. 790, 791.

Manavgat, Halka Açık Anonim Ortaklıklar, s. 304.

Bektaş, s. 795; Çetin/Töremiş/Cantimur, s. 70; Adıgüzel, s. 25.

Bektaş, s.795; Adıgüzel, s. 25.

Bektaş, s. 795.

Sönmez, s. 107, 108; Manavgat, Halka Açık Anonim Ortaklıklar, s. 305; Çetin/Töremiş/Cantimur, s. 70.
} 
konusu olduğu borsa kotundan çıkma hali yalnızca ortaklık genel kurul kararıla borsa kotundan çıkmaya ilişkindir. ${ }^{73}$

2.1.6 Bedelli sermaye artırımlarında elde edilen fonun kullanım şekli. Önemli Nitelikteki İşlemler Tebliği md. 5/1/g, bedelli sermaye artırımında elde edilen nakdin ortaklığın mevcut sermayesini aşmasını ve bununla birlikte ortaklığın ilişkili tarafa olan ve varlık devrinden kaynaklanan borcunun ödenmesinde kullanılmasını pay sahibine ayrılma hakkı tanıyan önemli nitelikteki işlem saymıştır.

Hükümde açıkça belirtildiği üzere SPK md. 23 kapsamında önemli nitelikte işlemden bahsedebilmek için öncelikle ortaklık genel kurul veya yönetim kurulu tarafından bedelli sermaye artırımı kararı verilmeli, ilişkili taraflar şirkete nakit dışı varlık devri yapmalı ve sermaye artırımından elde edilen nakit ilişkili tarafa olan borcun ödenmesinde kullanılacak olmalıdır. ${ }^{74}$ İlişkili tarafın tanımı ile ilgili olarak yukarıda 3.2.3 başlığı altında yapmış olduğumuz açıklamalar burada da geçerlidir.

\subsection{Diğer Şartlar}

a.) Ayrılma hakkını kullanmak isteyen kişinin söz konusu halka açık anonim ortaklıkta pay sahibi olması gerekir. Ancak ayrılma hakkını kullanmak isteyen pay sahibinin genel kurul toplantısının yapıldığı tarihteki her pay sahibi değil, önemli nitelikteki işlemin ilk defa kamuya açıklandığı (veya Önemli İşlemler Tebliği md. 10/3'e göre kamuya açıklanmış kabul edildiği) tarihte ortaklıkta pay sahibi olanların ayrılma hakkını kullanabileceğini kabul etmek amaca uygun düşecektir. ${ }^{75}$ Aksi taktirde, önemli nitelikteki işlemin gerçekleşme ihtimalini bildiği halde ortaklıktan pay satın alarak pay sahibi olan kişilerin ayrılma hakkını kullanabileceklerini ileri sürmek haksız sonuçlara sebebiyet verebilecektir.

Önemli İşlemler Tebliği md. 9/3'e göre pay üzerindeki intifa hakkı sahipleri ayrılma hakkını kullanamazlar. İntifa hakkı kural olarak TTK md. 432/2 gereğince, sahibine oy kullanma hakkı vermektedir. Ancak, TMK md. 794'e göre intifa hakk1, sahibine hakkın konusu olan mal üzerinde kullanma ve yararlanma hakkı vermekte malı tüketme hakk1 vermemektedir. Ayrılma hakkının kullanımı ise doğrudan malı (payı) tüketme anlamına geleceğinden ve bu yetki mülkiyet hakkının kapsamında olduğunda intifa hakkı sahibi ayrılma hakkını kullanamaz. Bu durumda ayrılma hakkının intifa hakkı sahibi ve pay sahibi tarafindan kullanılamaması gibi bir durum ortaya çıkmış olmaktadır. Önemli İşler Tebliği’nde bu hususa çözüm getirilmiştir. İlgili maddeye göre intifa hakkının söz konusu olduğu bir halde pay sahibi veya temsilcisinin genel kurula katılıp, önemli nitelikteki işleme karşı olumsuz oy kullanması ve muhalefetini toplantı tutanağına işletmesi gerekmektedir. ${ }^{76}$

\footnotetext{
3 Bektaş, s. 796; Adıgüzel, s. 25.

74 Manavgat, Halka Açık Anonim Ortaklıklar, s. 309; Adıgüzel, s. 30.

75 Bknz. Manavgat, Halka Açık Anonim Ortaklıklar, s. 386'deki zorunlu pay alım teklifi nedeniyle teklif yükümlüsüne dava açabilecek pay sahipleri hakkında yapılan açıklamalar.

76 Bektaş, s. 806.
} 
b.) Ayrılma hakkının kullanılabilmesi için SPK md. 24/1 ve Önemli İşlemler Tebliği md. 9/1 gereğince, pay sahibinin veya temsilcisinin önemli işleme ilişkin genel kurul toplantısına katılması ve olumsuz oy kullanması ve de muhalefet şerhini toplantı tutanağına işletmesi gerekir.

Bu konuda genel kurulda önemli nitelikte işleme ilişkin çekimser oy kullanmanın, ayrılma hakkının kullanılması için yeterli olup olmayacağı gündeme gelebilir. Çekimser oylar olumsuz oy olarak sayılsa da, SPK'nın açık hükmü gereği ayrılma hakkının kullanılması için yeterli değildir. Çünkü çekimser oy karara muhalefet edildiğini göstermez. Ancak, genel kurulda çekimser oy kullanıp, muhalefetini genel kurul tutanağına yazdıran pay sahibinin ayrılma hakkını kullanabilmesi gerekir. ${ }^{77}$

Tutanağa muhalefet geçirilirken, önemli karara muhalif kalındığının açıkça belirtilmesi gerekir. Bununla birlikte hangi nedenle karara muhalif kalındığının belirtilmesine gerek bulunmamaktadır. ${ }^{78}$

Ayrıca, ayrılma hakkının sahip olunan payların tümü için kullanılması gerekir. Ayrılma hakkı ile pay sahibine bir yatırım kararı alma imkânı tanındığından aynı pay sahibinin paylarının bir kısmı için ayrılma hakkını kullanmak istemesi düzenlemenin amacına ters düşer. ${ }^{79}$ Örneğin, ayrılma hakkını kullanmak isteyen pay sahibinin payları çeşitli imtiyazlara sahip olabilir. Bu durumda pay sahibi sadece imtiyazsız paylar için ayrılma hakkını kullanamaz. ${ }^{80}$ Keza Önemli İşlemler Tebliği md. 9/9 açıkça buna imkan tanımamıştır. Maddeye göre "ayrılma hakkını kullanmak isteyen pay sahipleri, bu hakkı grup ayrımına bakllmaksızın sahip oldukları payların tamamı için kullanmak zorundadr."

c.) Ayrılma hakkının kullanım şartlarından biri olan genel kurula katılıp, işleme olumsuz oy vererek muhalefetin toplantı tutanağına işletilmesinin bir istisnası bulunmaktadır. SPK md. 24/2 ye göre, pay sahibinin önemli nitelikteki işlemlere ilişkin genel kurul toplantısına katılmasının haksız bir biçimde engellenmesi, genel kurul toplantısına usulüne uygun davet yapılmaması veya gündemin usulüne uygun bir biçimde ilan edilmemesi hâllerinde, genel kurul kararlarına muhalif kalma ve muhalefet şerhini tutanağa kaydettirme şartı aranmayacak ve ilgili pay sahibi doğrudan ayrılma hakkını kullanabilecektir. SPK md. 24/2'de belirtilen hallerin varlığının davacı tarafından ispat edilmesi gerekmektedir. ${ }^{81}$ Genel kurula çağrı usulü SPK md. 29'da düzenlenmiştir. SPK md. 29/1'e göre, ortaklık pay sahiplerini genel kurul toplantısına, esas sözleşmede gösterilen şekilde, ortaklığın internet sitesi ve KAP ile Kurulca belirlenen diğer yerlerde yayımlanan ilanla çağırmak zorundadır.

\footnotetext{
Adıgüzel, s.33; Aksi yönde, Bektaş, s. 803 vd.

78 Adıgüzel, s.34; Sönmez, s. 118.

79 Manavgat, Halka Açık Anonim Ortaklıklar, s. 328; Adıgüzel, s. 39; Altan, s. 155.

80 Bektaş, s. 813; Adıgüzel, s.39.

${ }^{81}$ Adıgüzel, s. 34.
} 
Bu çağrı, ilan ve toplantı günleri hariç olmak üzere, toplantı tarihinden en az üç hafta önce yapılır. SPK md. 29/2'ye göre nama yazılı ihraç edilmiş olup borsada işlem gören paylar hakkında da TTK md. 414/1 değil, SPK'daki kural uygulanır.

TTK md. 446/1/b'de genel kurul kararlarının iptaline ilişkin hükümde genel kurula katılmasına rağmen oy kullanmasına engel olunan kişilerin iptal davası açabilecekleri düzenlenmişken, SPK md. 24/2'de böyle bir düzenleme bulunmamaktadır. Bununla birlikte, bir pay sahibi önemli nitelikteki kararın alınacağı genel kurula katılmış fakat (örneğin oy kullanırken genel kuruldan dışarı çıkartılmak suretiyle) oy kullanması engellenmiş ise, ayrılma hakkının kullanılabileceğinin kabul edilmesi amaca uygun düşecektir. ${ }^{82} \mathrm{Bu}$ durumun yanı sıra, genel kurulun usulüne uygun ilan edilmemesine rağmen, pay sahibi genel kurula katılmış ise bu ihtimalde ayrılma hakkının kullanılabilmesi için olumsuz oy kullanma ve muhalefetini tutanağa geçirme şartlarının aranması gerektiğini kabul etmek uygun olacaktır. ${ }^{83}$

\section{Ayrılma Hakkının Kullanılması}

Ayrılma hakkının kullanılacağı önemli nitelikteki işleme ilişkin kararların alınacağı genel kurulla ilgili olarak ortaklığın ve pay sahibinin bir takım işlemler yapması gerekmektedir. Bu işlemler genel kurul öncesi ve sonrası yapılması gereken işlemler olarak ikiye ayrılabilir.

\subsection{Ayrılma Hakkını Kullanma Yöntemi}

3.1.1 Genel kurul öncesinde yapılması gereken işlemler. Önemli İşler Tebliği md. 9/4'e göre, “önemli nitelikteki işlemlerin görüşüleceği genel kurul toplantısının gündeminde, bu kararlara muhalefet oyu kullanacak pay sahiplerinin ortaklıktan ayrilma hakkının bulunduğu hususu, bu hakkın kullanılması durumunda payların ortaklık tarafından satın alınacağı birim pay bedeli ve ayrılma hakkı kullanılmasına ilişkin işleyiş sürecin yer alması" gerekmektedir. Bu doğrultuda gündemde ayrılma hakkının varlığı açısından genel bilgi verilmesi ve muhalefetin tutanağa yazdırılması gerektiğinin belirtilmesi de gerekir. ${ }^{84}$ Ancak davette bu hususun bildirilmemesi ayrilma hakkının kullanılmasına zarar vermemektedir. Pay sahibi genel kurul toplantısına katılmamış ise SPK md. 24/2 uyarınca davet usulüne uyulmaması nedeniyle ayrılma hakkının kullanımı için gerekli olan olumlu koşulları yerine getirmeksizin ayrılma hakkını kullanabilir. ${ }^{85}$

\footnotetext{
Adıgüzel, s. 35; Manavgat, Halka Açık Anonim Ortaklıklar, s. 327.

Adıgüzel, s. 35; Manavgat, Halka Açık Anonim Ortaklıklar, s. 328.

Adıgüzel, s. 37.

Adıgüzel, s. 37; Bektaş, s. 809.
} 
Önemli İşler Tebliği md. 10/6'ye göre aynı genel kurul toplantısında birden fazla önemli nitelikteki işlem karara bağlanacak ise her bir işlemin ayrı bir gündem maddesi olarak görüşülmesi ve her bir işlem için belirlenecek ayrılma hakkı kullanım fiyatının gündemde ayrıca gösterilmesi gerektiği belirtilmiştir. Gündemde yer alan işlemlerden herhangi birine olumsuz oy kullanan ve muhalefetini tutanağa yazdıran pay sahibi ayrılma hakkını kullanabilecektir. ${ }^{86}$

Gündemde ayrılma hakkıyla ilgili bilgilere hiç yer verilmemesi ya da eksik bilgiye yer verilmesi gibi gündemin kanuna aykırı biçimde düzenlenmesi halinde genel kurul kararının iptali davası açılıp açılamayacağı ve beraberinde ayrılma hakkının kullanılabilip kullanılamayacağının değerlendirilmesi gerekir. Pay sahibi eğer ki genel kurul toplantısına katılmış ve olumlu oy kullanmış ise TTK md. $446^{87}$ ya göre iptal davası açabilecektir. Ancak bu durumda ayrılma hakkını kullanması mümkün olmayacaktır. ${ }^{88}$

3.1.2 Genel kurul sonrası yapılması gereken işlemler. Usulüne uygun bir şekilde yapılmış çağrı ve ilan edilmiş genel kurula katılıp olumsuz oy kullanan ve muhalefetini genel kurul tutanağına işleten veya SPK md. 24/2'de belirtilen bir durumla karşılaşan pay sahibi ayrılma hakkını kullanabilecek hale gelmiştir.

Ayrılma hakkının ortaklığa bir bildirim gönderilmesi yoluyla kullanılması gerekir. Önemli İşlemler Tebliği md. 9/6'ya göre ortaklık, ayrılma hakkını genel kurul tarihinden itibaren en çok altı iş günü içinde kullandırmaya başlamak zorundadır. Ayrıca, ayrılma hakkının kullanım süresi ortaklık tarafından belirlenecektir, ancak bu süre on iş gününden az yirmi iş gününden fazla olamaz. Pay sahibinin bu süreler içinde ayrılma hakkını kullanacağını ortaklığa bildirmesi gerekmektedir. Bu süreler geçtikten sonra ayrılma hakkı kullanılamaz. ${ }^{89}$

Önemli İşlemler Tebliği md. 9/7'ye göre ayrılma hakkının bir aracı kurum vasıtasıyla kullanılması zorunludur. Bunun nedeni, halka açık ortaklık tarafından satın alınacak payların borsada işlem gören fiyat üzerinden ağırlıklı ortalama esas alınarak ödenmesidir. ${ }^{90}$ Ancak, payları borsada işlem görmeyen ortaklıkların aracı kurum kullanma zorunluluğuna, talep üzerine Kurulca muafiyet verilebilir. Önemli İşlemler Tebliği md. 9/7'ye göre ayrılma hakkını kullanacak pay sahipleri ayrılma hakkına konu payları, ortaklık adına alım işlemlerini gerçekleştiren aracı kuruma, kamuya açıklanan ayrılma hakkının kullanım sürecine ilişkin ilan çerçevesinde ve genel hükümler doğrultusunda teslim ederek satışı gerçekleştirir. Ancak kaydi

\footnotetext{
86 Adıgüzel, s. 38; Bektaş, s. 810.

87 TTK 446'ya göre “Toplantıda hazır bulunsun veya bulunmasın, olumsuz oy kullanmış olsun ya da olmasın; çağrının usulüne göre yapılmadı̆̆ını, gündemin gereği gibi ilan edilmediğini, genel kurula katılma yetkisi bulunmayan kişilerin veya temsilcilerinin toplanttya katılip oy kullandlklarını, genel kurula katılmasına ve oy kullanmasına haksı olarak izin verilmediğini ve yukarıda sayılan aykırlıkların genel kurul kararının alınmasında etkili olduğunu ileri süren pay sahipleri’' iptal davası açabilir.

88 Bektaş, s. 808.

89 Adıgüzel, s. 47

90 Adıgüzel, s. 39.
} 
sistemde payın teslimi söz konusu olmadı̆̆ından pay sahibinin başvurusu üzerine payı MKK'daki hesabından çıkartılarak bu işlem gerçekleştirilecektir. ${ }^{91}$ Ayrılma hakkının kullanılması için ortaklığın kabul beyanına gerek olmadığından aracı kurum payları ortaklık adına satın alır ve ayrılma hakkının kullanılması için kendisine başvuran pay sahipleri ile satış işlemlerini gerçekleştirir. Pay bedelleri en geç satışı takip eden işgünü içinde ödenmek zorundadır. ${ }^{92}$

Ayrılma hakkının kullanılması ile ilgili olarak, ayrılma hakkını doğuran önemli nitelikteki işlemin karara bağlandığı genel kurul kararının iptal edilmesi veya butlan sebebiyle kesin hükümsüz olması durumunda pay sahibinin ayrılma hakkının bu durumdan nasıl etkileneceği sorunu gündeme gelebilir. SPK md. 23 ve 24 'te TTK, TMK ve sair kanunlarda öngörülen yokluk, butlan ve iptal hallerinin ayrılma hakkını düzenleyen hükümler karşısında kullanılmayacağını ifade eden bir düzenleme bulunmamaktadır. Dolayısıyla, genel hükümler çerçevesinde halka açık anonim ortaklığın önemli nitelikteki işlemin karara bağlandığı genel kurul kararının mahkemece iptal edilmesi veya butlanla batıl olduğunun tespit edilmesi halinde, ilgili mahkeme kararı geçmişe doğru etki edecek ve ilgili önemli nitelikteki işlem de ortadan kalkacaktır. Bu nedenle, ayrılma hakkının kullanılması da mümkün olmayacaktır.93

\subsection{Ayrılma Hakkının Kullanımının Engellenmesi}

Önemli İşlemler Tebliği'ne göre ortaklığın yönetim kurulu belirli şartlar dahilinde, genel kurulda alınan önemli nitelikteki işleme ilişkin kararın gerçekleştirilmemesini sağlama ve bu yolla önemli nitelikteki işleme muhalif kalan pay sahiplerinin ayrılma haklarını kullanmasına engel olma hakkına sahiptir. ${ }^{94}$ Ancak, Önemli İşler Tebliği md. 9/5'e göre, yönetim kurulunun bu hakkını kullanabilmesi için önemli nitelikte işleme onay verilmesinin tartış1lacağı genel kurul gündeminde işlemden vazgeçme olasılığının ve bunun koşullarının belirtilmesi gerekir. İlgili maddede iki tane vazgeçme hali öngörülmüştür. Bunlar i) pay sahiplerince ayrılma hakkının kullanılması sonucunda ortaklığın katlanmak zorunda kalabileceği toplam maliyetin belirlenen tutarı aşması ya da belirlenen orandan fazla paya sahip ortakların olumsuz oy kullanması veya ii) belirlenen nitelikteki ortakların olumsuz oy kullanması halidir.

Birinci koşul ayrılma hakkının yaratacağı maliyet ile ilgilidir. Buna göre ortaklık, gündemin ilanından önce azami ayrılma hakkı maliyetini belirlemeli ve genel kurul gündeminde yer vermelidir. Ancak, ayrılma hakkının yaratacağı azami maliyetin gündemde belirtilmesi tek başına bir anlam ifade etmeyebilir. Ayrılma hakkının ortaklığa

\footnotetext{
91 Manavgat, Halka Açık Anonim Ortaklıklar, s. 341.

92 Adıgüzel, s. 39; Bektaş, s. 815; Manavgat, Halka Açık Anonim Ortaklıklar, s. 341.

93 Kurul'un bir davaya ilişkin olarak aldığ 18.05.2015 ve 1179 sayılı ve 21.10.2015 ve 11462 sayılı Kararları ve Bakırköy 1 . Asliye Ticaret Mahkemesi'ne sunulan 11.05.2016 tarihli Ek Bilirkişi Raporu, https://www.kap.org.tr/tr/Bildirim/536241, (Çevrimiçi), 10 Ocak 2017.

94 Adıgüzel, s. 39; Manavgat, Halka Açık Anonim Ortaklıklar, s. 338.
} 
getireceği maliyet, ayrılma hakkının koşullarını yerine getiren ortakların sahip oldukları payların miktarına bağlıdır. Ayrılma hakkı kullanılması halinde pay başına ödenecek tutar genel kurul gündemi hazırlanırken belli olmaktadır. Bu nedenle, ayrılma hakkını kullanabilecek ortakların azami pay oranının vazgeçme koşulu olarak gösterilmesi ve genel kurul gündeminde yer verilmesi de birinci koşulun gerçekleşmesi için yeterlidir. Tebliğde belirtilen ikinci koşul ise önceden belirlenmiş nitelikteki ortakların olumsuz oy kullanmasıdır. Örneğin, dağıtım alanında faaliyet gösteren ve pay sahiplerinin çoğunun ortaklığın işleyişini kolaylaştıran bayiler olduğu veya belirli bir yöre ve işletme çalışanının yoğun olarak pay sahibi olduğu bir ortaklıkta söz konusu ortakların ayrılma hakkını kullanabilecek duruma gelmesi, ortaklı̆̆ın pay sahipliği yapısının korunması için önemli nitelikteki işlemden vazgeçmeyi haklı kılabilir. ${ }^{95}$ Vazgeçmeyi haklı kılacak olan koşulların keyfi uygulamalara yol açmaması için koşulların objektif olarak belirlenmesi, örneğin olumsuz oy kullanması koşuluna bağlanan pay sahipleri için ortaklık için önem arz eden makul nitelikler veya asgari oranın belirlenmesi ya da azami maliyet tutarının önemli nitelikteki işlemin maliyetiyle orantılı olması gerekir. ${ }^{96}$

Yönetim kurulunun önemli nitelikteki kararı uygulamama hakkının bulunması, TTK'ya göre yönetim kurulunun genel kurulun aldığı kararları uygulama görevine bir istisna getirmemektedir. Çünkü yönetim kurulunun önemli nitelikteki işlemi gerçekleştirmekten vazgeçebilmesi için de SPK md. 9/5/ikinci cümle gereğince genel kurul gündeminde işlemden vazgeçilebileceğine ilişkin gündem maddesi bulunması ve genel kurulun vazgeçmeye ilişkin gündem maddesini onaylaması yani yönetim kuruluna kararı uygulamama yetkisi vermesi gerekir. ${ }^{97}$

Genel kurulda önce önemli nitelikteki işleme onay verilmesi ve vazgeçme koşulları oluşursa vazgeçmenin karara bağlanması gerekir. Önemli İşler Tebliği md. 9/5/son cümle gereğince gündem maddesinin oylanmasında oydan yoksunluk halleri geçerli olmaz. Toplantıda hazır bulunan tüm pay sahipleri veya vekilleri oy kullanabilirler. Oydan yoksunluk halleri TTK 436'da belirtilen pay sahiplerinin kişisel alakaları sebebiyle alınacak genel kurul kararıyla herhangi bir menfaat çatışması yaşanmaması için düzenlenen hallerdir. Ancak, önemli nitelikteki işlemden vazgeçmeye ilişkin gündem maddesinin oylanması ortaklığın menfaatini ilgilendirdiğinden oydan yoksunluk hali uygulanmamaktadır. ${ }^{98}$

\section{Ayrılma Hakkının Doğmadığı Haller}

Ayrılma hakkının kullanılabilmesi için önemli nitelikteki işlemin Önemli İşlemler Tebliği md. 12 'de belirtilen ayrılma hakkının doğmadığı haller arasında sayılmış

\footnotetext{
Manavgat, Halka Açık Anonim Ortaklıklar, s. 339.

96 Manavgat, Halka Açık Anonim Ortaklıklar, s. 340.

97 Adıgüzel, s. 40; Bektaş, s. 811.

98 Manavgat, Halka Açık Anonim Ortaklıklar, s. 339; Adıgüzel, s. 40.
} 
olmaması gerekir. Önemli İşlemler Tebliği’nde ayrılma hakkının doğmayacağı belirtilen hallerin bir kısmında pay sahibi pay alım teklifi yoluyla korunmuştur. Bazı hallerde ise pay sahibini koruma gerekliliği doğmamaktadır. ${ }^{99}$

Tebliğde düzenlenen hallerden ilki önemli nitelikteki işlemin mevzuat gereği zorunlu olarak yapılmasıdır. Örneğin rekabet hukuku mevzuatı gereğince, ortaklık hakim durum yaratmaktan kaçınmak için bölünme yoluna gidebilir. Bu durumda ortaklığın menfaati tebliğin ilgili hükmü gereğince pay sahiplerinin menfaatine üstün tutulacak ve pay sahibi ayrılma hakkını kullanamayacaktır. ${ }^{100}$

Tebliğde sayılan ikinci husus, yönetim kontrolünün bir kamu kurumunda olduğu ortaklıklarda gerçekleşen önemli nitelikteki işlemlerdir. Bu düzenlemenin amacının ayrılma hakkının maliyetine kamu kurumunun katlanmaması olduğu söylenebilir. ${ }^{101}$

Üçüncü hal, ortaklıkta imtiyazlı pay bulunması halinde tüm imtiyazların bedelsiz olarak kaldırılması veya konu ve kapsam bakımından daraltılması işlemleridir. Bu doğrultuda, SPK md 23/1/ç hükmü dikkate alındığında imtiyazların kapsamının genişletilmesi halinde ayrılma hakkının kullanılabileceği söylenebilir. Bunun yanı sıra, imtiyazın konusunun değiştirilmesi, öncelikle mevcut imtiyazın sona erdirilmesini ve daha sonra yeni bir imtiyazın yaratılmasını gerektirdiğinden, böyle bir ihtimalde de ayrılma hakkının kullanılabileceğini kabul etmek gerekir. ${ }^{102}$

Dördüncü hal, yatırım ortaklıklarının yatırım ortaklığı niteliğinin değiştirilmesi, yitirilmesi ve bu kapsamda yapılan imtiyaz değişiklikleridir. Bu hal SPK md. 26/5 uyarınca zorunlu pay alım teklifi yoluyla korunmuştur. Bunun dışında, önemli nitelikteki işlem sonucunda pay alım teklifi zorunluluğu getirilen veya gönüllü olarak pay alım teklifi yapılması Kurulca uygun görülen işlemler ile birleşme amaçlı ortaklığın taraf olduğu birleşme ve sona erme işlemleri pay alım teklifi ile korunması sebebiyle ayrılma hakkının kullanılmasına imkan tanınmamıştır. Ayrıca, bölünen ortaklığın ortaklık yapısının korunduğu yeni ortaklık kurulması suretiyle bölünme işlemleri ve kolaylaştırılmış usulde birleşme ve bölünme işlemleri ortakların korunmasını gerektirmemesi sebebiyle ayrılma hakkının kullanılamayacağı bir hal olarak düzenlenmiştir. ${ }^{103}$

Gayrimenkul yatırım ortaklıklarının portföylerinde yer alan varlıkları kiraya vermesi, gayrimenkul yatırım ortaklıklarının portföylerinde yer alan varlıklar üzerinde III-48.1 sayılı Gayrimenkul Yatırım Ortaklıklarına İlişkin Esaslar Tebliği hükümleri çerçevesinde ayni hak tesis edilmesi ve ortaklıkların kendi tüzel kişilikleri adına ve finansal tablolarında tam konsolidasyona dahil ettikleri ortaklıklar lehine

\footnotetext{
Manavgat, Halka Açık Anonim Ortaklıklar, s. 331.

100 Manavgat, Halka Açık Anonim Ortaklıklar, s. 329.

101 Manavgat, Halka Açık Anonim Ortaklıklar, s. 330.

102 Manavgat, Halka Açık Anonim Ortaklıklar, s. 330.

103 Manavgat, Halka Açık Anonim Ortaklıklar, s. 330, 331.
} 
mal varlığı üzerinde ayni hak tesis etmesi mevzuatın yapılmasına imkan tanıdığı işlemlerdir ve ayrılma hakkının kullanılmasına sebebiyet vermez. Kurulca uygun görülmesi koşuluyla, Kurul düzenlemelerine göre hazırlanmış finansal tablolarına göre sermayesinin en az yarısı karşılıksız kalan ortaklıkların mal varlığ 1 içinde yer alan ancak ekonomik bir değeri bulunmayan mal varlıklarının devrinin ortaklıkların söz konusu sermaye kaybını sona erdireceği özel amaçlı bağımsız denetim raporu ile tespit edilen işlemler TTK md. 376 kapsamında sermaye kaybına çözüm getirmek amacıyla yapılan işlemlerdir ve ayrılma hakkını doğurmaz. ${ }^{104}$

Önemli Nitelikteki İşlemler Tebliği md. 12/f’te pay sahibine ayrılma hakk1 vermeyen üç hal öngörülmüştür. İlk olarak, önemli nitelikteki işlemin adli makamlarca İIK çerçevesinde verilen bir karar uyarınca veya kamu alacağının tahsili amacıyla yapılması halinde yapılan işlem ortaklığın kararına dayanmadığından ayrılma hakkı doğmayacaktır. İkinci olarak, satılan varlığın finansal kiralama yoluyla hemen geri alınması durumunda ortaklık fon temin etmek amacıyla bu tür bir işlem yapmakta ve söz konusu varlığı kullanmaya devam etmektedir. Bu nedenle böyle bir halde de pay sahibinin ayrılma hakkını kullanması ve ortaklık açısından işlemin maliyetinin artırılması haklı görülmemiştir. Son olarak, kira sertifikası, varlığa veya ipoteğe dayalı menkul kıymet veya teminatlı menkul kıymet ihracı amaciyla yapılan mal varlığı devir işlemleri ilgili mevzuat gereği söz konusu sermaye piyasası araçlarının ihracı için yapılması zorunlu olan işlemlerdir ve bu işlemler sonucunda ortaklık fon temin etmektedir. $\mathrm{Bu}$ nedenle, pay sahibinin korunması gerekmediğinden ayrılma hakkını kullanma imkanı tanınmamıştır. ${ }^{105}$

Önemli İşlemler Tebliği md. 12/2’ye göre “ayrılma hakkının doğmadiğı hallerde; dĭger ilgili düzenlemeler uyarınca genel kurul yapılma zorunluluğu bulunduğu haller hariç olmak üzere, yönetim kurulu kararı alınması yeterli olup, ayrıca genel kurul toplantısı yapılması gerekmez. Diğer ilgili düzenlemeler uyarınca genel kurul yapılma zorunluluğu olan hallerde ise, toplantı gündemine ayrılma hakk doğmadığına ilişkin yönetim kurulu beyanı eklenir. Ayrıca her durumda, bu madde kapsamında değerlendirilen işlemlere ilişkin olarak gerekçeli yönetim kurulu kararl, ilgili bilgi ve belgelerle birlikte Kurulun özel durumlara ilişkin düzenlemeleri uyarınca kamuya açıklanır."

\section{Ayrilma Bedeli}

Ayrılma bedeli, pay sahibinin ayrılma hakkının nakde dönüştürülmesidir. Ayrılma hakkının amacına hizmet edebilmesi için ayrılma hakkını kullanan pay sahibinin payının adil bir değer üzerinden satın alınması gerekmektedir. ${ }^{106}$ SPK md. 24/1 ve Önemli İşlemler Tebliği md. 10/1'de bu bedel, "payları borsada işlem gören ortaklıkların

\footnotetext{
104 Manavgat, Halka Açık Anonim Ortaklıklar, s. 330.

105 Manavgat, Halka Açık Anonim Ortaklıklar, s. 331.

106 Manavgat, Halka Açık Anonim Ortaklıklar, s. 332; Bektaş, s. 815, 816; Adıgüzel, s. 40,41; Çetin/Töremiş/Cantimur, s. $174,175$.
} 
payları için işlemin ilk defa kamuya açıklandığı tarihten önceki, açıklanan tarih hariç olmak üzere, otuz gün içinde borsada oluşan düzeltilmiş ağırlıklı ortalama fiyatların aritmetik ortalaması olarak" belirlenmiştir. Bedelin bu şekilde belirlenmesinin öngörülmesinde amaç, önemli nitelikteki işlem bilgisinden etkilenmemiş güncel fiyatın bulunabilmesidir. Ancak, SPK md. 24/1'e göre ayrılma bedelinin hesaplanmasında ortaklığın değerinin dikkate alınmaması sebebiyle güncel fiyatın her zaman adil değeri ifade ettiğini söylemek mümkün olmayabilecektir. Özellikle piyasaların iyi işlemediği veya dönemsel özellikler sebebiyle fiyatın normalden düşük olduğu dönemlerde ortaklı̆̆ın önemli nitelikte bir işlem yapması ve pay sahibinin yukarıda ifade edilen şekilde hesaplanacak değer üzerinden ayrılma hakkını kullanmaya veya ortaklıkta kalmaya zorlanmaya çalışması ayrılma hakkının amacına hizmet etmemektedir. ${ }^{107}$ Önemli İşlemler Tebliği md. 10/2'de ise payları borsada işlem görmeyen ortaklıkların payları için ayrılma hakkı kullanım fiyatı ile bu fiyatın adil ve makul olduğunun tespiti amaciyla Kurulun ilgili düzenlemelerine göre bir değerleme raporu hazırlanması gerektiği belirtilmiş ve bu raporun önemli nitelikteki işlemin görüşüleceği genel kurul toplantısı gündemi ile birlikte açılanması öngörülmüsstür.

SPK md. 24/1 ve Önemli İşlemler Tebliği md. 10/1'de belirtilen otuz günlük sürenin başlangıcı önemli işlemin kamuya ilk defa açıklandığı tarihtir. Önemli İşlemler Tebliği md. 10/3'e göre kamuya ilk defa açıklanma tarihi, "ortaklık tarafindan kamuya açıklama yapılmamış olması veya açıklamanın zamanında yapılmamışolması ya da payları borsada işlem gören ortakliklar için KAP'ta açıklanma tarihi, payları borsada işlem görmeyen ortakllklar için ise Kurul ve ortaklik internet sitesi dişında başka bir yerde açıklama yapılmış olması hallerinde; işleme iliş̧kin yönetim kurulu kararının özel durumlara ilişkin Kurul düzenlemeleri uyarınca kamuya açıklanması gereken tarih veya herhalde ortakllk yetkililerince yönetim kurulu kararından daha önce açıklama yapılmış olması halinde bu tarihtir". Md 10/4'e göre "Önemli nitelikteki bir işleme ilişkin birden fazla sayıda özel durum açıklamasının yapıldığı durumlarda, söz konusu işleme ilişkin fiyat, tutar, oran ve benzeri bilgilere yer verilip verilmediğine dikkat edilmeksizin yapılması planlanan işleme ilişkin niyetle ilgili olarak kamuya yapılan ilk açıklama tarihi esas alınır."

Önemli İşlemler Tebliği md. 9/7 gereğince, ayrılma hakkının payları borsada işlem gören ortaklıklarda aracı kurum vasıtasıyla kullanılması zorunludur. Ayrılma hakkının tam ve nakden ödenmesi gerekmektedir. Ayrıca, Önemli İşlemler Tebliği md. 10/6'a göre bir genel kurul toplantısında birden fazla önemli nitelikteki işlemin görüşülmesi ve ilgili genel kurula katılan bir pay sahibinin birden fazla önemli nitelikteki işlem için olumsuz oy kullanması ve muhalefet şerhini toplantı tutanağına işletmesi halinde, ilgili pay sahibine ödenecek ayrılma bedelinin belirlenmesinde pay sahibinin olumsuz oy kullandığı tüm önemli nitelikteki işlemlere ilişkin ayrılma bedellerinden en yükseğinin dikkate alınması gerekir.

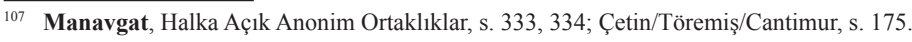


Payları borsada işlem görmeyen ortaklıklarda pay değeri değerleme raporuyla belirleneceğinden, rapordaki bedeli uygun bulmayan pay sahibinin pay bedelinin tespiti için dava açabileceğini kabul etmek gerekir. ${ }^{108}$ Pay bedelinin tespitine ilişkin açılacak davanın süresi SPK ve ikincil mevzuatta belirtilmemiştir. Önemli İşlemler Tebliği md. 9/6'da, ayrılma hakkının kullandırılmasının genel kurul tarihinden itibaren en çok altı iş günü içinde başlayacağ 1 ve kullanım süresinin on iş gününden az yirmi iş gününden fazla olmayacağı öngörüldüğünden, değerleme raporunda belirtilen değere itiraz eden pay sahibinin belirlenen değeri kullanım süresi içinde haklarını saklı tutarak kabul etmesi ve daha sonra talep ettiği ek değer için bedel tespiti için dava açmasi uygun olacaktır. ${ }^{109}$ Ancak, pay sahibi değerleme raporunda belirtilen bedeli ihtirazı kayıtla kabul ettikten sonra, açtığı dava sonucunda mahkemece tespit edilen bedel talep ettiğinden daha düşük çıksa dahi, pay sahibi ayrılma hakkından dönemeyecektir. ${ }^{110}$

Pay sahibinin ayrılma hakkı borsada işlem gören ortaklıklar için aracı kuruma başvurularak payın pay sahibinin MKK'daki hesabından çıkartılması, payları borsada işlem görmeyen ortaklıklar için ise aracı kuruma teslim ettikleri andan itibaren son bulur. Pay bedeli satışı takip eden iş günü ödenecektir. Önemli İşler Tebliği md. 9/8'te, genel kurulda önemli nitelikteki işlemler bakımından olumsuz oy kullanarak muhalefet şerhini toplantı tutanağına işleten pay sahiplerinin satışın bitip payların teslimi anına kadar söz konusu genel kurul toplantısı gündeminde bulunan diğer gündem maddeleri açısından ortaklık haklarını kullanmaya devam edecekleri düzenlenmiştir.

Ayrılma hakkını kullanan pay sahibinin paylarının ortaklıkça satın alınması sonucunda pay sahibine ait paylar ortaklığa geçmekte, yani ortaklık kendi paylarını iktisap etmiş olmaktadır. ${ }^{111}$ Halka açık anonim ortaklığın kendi paylarını satın alması SPK md. 22 ve Geri Alınan Paylar Tebliği uyarınca belirli şartlara ve sınırlamalara tabidir. Geri Alınan Paylar Tebliği md. 9/1'e göre ortaklık, esas veya çıkarılmış sermayesinin yüzde onundan fazlasına tekabül eden paylarını satın alamaz. Ancak, Önemli İşlemler Tebliği md. 10/8'e göre geri alma sınırına ilişkin bu oran, ayrılma hakkının kullanılması halinde uygulanmaz. Bu sayede, ortaklığın ayrılma hakkını kullanmak isteyen pay sahiplerine kendi paylarını iktisap edecek sınırın dolduğunu ileri sürülmesi engellenmiş olmaktadır. ${ }^{12}$ Bununla birlikte, ortaklık tarafından satın alınan payların ortaklığın esas veya çıkarılmış sermayesinin yüzde onunu geçmesi durumunda bu oranı aşan kısmın, Geri Alınan Paylar Tebliği md. 19/3'e göre herhangi bir kayba yol açmadan devirleri mümkün olur olmaz ve her halükarda elde edilmelerinden itibaren üç yıl içinde elden çıkartılması gerekmektedir. Bu süre zarfında elden çıkarılmayan payların sermaye azaltımı suretiyle derhal itfa edilmesi zorunludur.

\footnotetext{
Bektaş, s. 818; Adıgüzel, s. 43; Özdoğan, s. 739.

109 Bektaş, s. 819; Adıgüzel, s. 43.

10 Bektaş, s. 819, 820.

111 Adıgüzel, s. 44.

112 Bektaş, s. 768.
} 


\section{Ayrılma Hakkı Ve Önemli Nitelikteki İşlemlere İlişskin Yükümlülüklere Aykırılığın Sonuçları}

\subsection{Kurulca İptal Davası Açılması}

Önemli nitelikteki işlemlerin usule aykıı biçimde gerçekleştirilmesi durumunda ilgili işlem geçerli olacaktır. Ancak, SPK md. 23/2'ye göre Kurul'un, TTK'nın genel kurul kararlarının iptaline ilişkin hükümleri çerçevesinde ilgili işlemin SPK md. 23/1'de belirtilen zorunluluklara uyulmaksızın yapıldığı gerekçesiyle dava açma imkanı bulunmaktadır. Bu kapsamda, Kurul'un iptal davası açabileceği halleri SPK md. 23/1'deki haller ile Önemli İşlemler Tebliği'nde belirtilen usullere uyulmayan haller ile sınırlamak gerektiği düşünülebilir. Ancak, Kurul'un iptal davasını sadece bu hallerle sınırlamak ve ayrılma hakkını düzenleyen SPK md. 24'ü kapsam dışında bırakmak amaca uygun düşmeyecektir. Bu nedenle, Kurul'un ilgili işlemin SPK ve Önemli İşlemler Tebliği’nde belirtilen usullere aykırılıkların yanı sıra, ilgili işlemin hiç veya gereği gibi usulüne uygun bir biçimde genel kurul onayına sunulmaması, ayrılma bedelinin gündemde eksik gösterilmesi veya ayrılma bedeline hiç yer verilmemesi gibi aykırılıklar halinde de iptal davası açma yetkisinin bulunduğunu kabul etmek gerekir. ${ }^{113}$

Ayrıca, SPK md. 23/2'de SPK'nın TTK'nın genel kurul kararlarının iptaline ilişkin hükümler çerçevesinde dava açabileceği belirtilmiştir. Ancak, önemli nitelikteki işlem genel kurulun onayına sunulmamışsa veya yönetim kurulu kararının alınması veya kamuya açıklanması aşamasında hukuka aykırılık var ise, genel kurul kararlarının iptalinde izlenen dava açma süresi ve usulünün söz konusu işlemin iptali ile ilgili olarak da kıyasen uygulanması gerekir. Ancak iptal sebeplerinin SPK md. 23/2'de belirtildiği üzere SPK md. 23/1'de belirtilen zorunluluklar çerçevesinde değerlendirilmesi gerekir. Bu kapsamda, SPK'nın önemli nitelikteki işlemin kanuna, esas sözleşme hükümlerine ve dürüstlük kuralına aykırılığı nedeniyle dava açma yetkisi olmadığı değerlendirilmektedir. ${ }^{114}$ Bununla birlikte, SPK md. 92'ye göre, ihraçı statüsünde olan ortaklıkların kanuna, sermaye piyasası mevzuatına, esas sözleşme hükümlerine, fon iç tüzüğüne veya işletme maksat ve mevzuuna aykırı görülen durum ve işlemleri sebebiyle sermayenin veya malvarlığının azalmasına veya kaybına yol açtığının Kurulca tespit edilmesi şartıyla, Kurul'un işlemlerin hukuka aykırılı̆̆ının Kurulca tespiti tarihinden itibaren 3 ay ve her halde durum ve işlemin gerçekleştiği tarihinden itibaren 3 yıl içinde iptal davası ve 5 yıl içinde butlan veya yokluğun tespiti davası açma hakkı bulunmaktadır. SPK md. 92'de öngörülen tedbirler için işlem türleri bakımından bir sınırlama getirilmemiştir. Bu nedenle, kanuna, sermaye piyasası mevzuatına, esas sözleşme hükümlerine, fon iç tüzüğüne veya işletme maksat ve mevzuuna aykııı olan ve sermayenin veya malvarlığının azalmasına veya kaybına yol açan her türlü işlem, durum, yönetim kurulu veya genel kurul kararı hakkında söz konusu tedbir uygulanabilir. ${ }^{115}$

\footnotetext{
13 Manavgat, Halka Açık Anonim Ortaklıklar, s. 316.

114 Manavgat, Halka Açık Anonim Ortaklıklar, s. 316.

115 Çetin/Töremiș/Cantimur, s. 204.
} 
Bu kapsamda, Kurul SPK md. 23'te belirtilen zorunluluklara uyulmaksızın gerçekleştirilen önemli nitelikteki işlemin ortaklığın sermayesinin ve malvarlığının azalmasına yol açması koşuluyla, ilgili işlem veya genel kurul ya da yönetim kurulu kararı için aykırılığın tespiti tarihinden itibaren 3 ay ve herhalde işlemin gerçekleştiği tarihten itibaren 3 yıl içinde iptal davası ve 5 yıl içinde butlan veya yokluğun tespiti davası açma hakkının bulunduğunu söylemek mümkündür. ${ }^{116}$ Ancak, Kurul'ca iptal veya yokluk yada butlan davası açılmadan önce aşağıda 6.4 numaralı başlık altında incelemiş olduğumuz diğer tedbirlerin alınmasının daha uygun olacağı değerlendirilmektedir. ${ }^{117}$

\subsection{Kurulca İdari Para Cezası Verilmesi}

Ayrıca Kurul, SPK md. 23'teki önemli nitelikteki işlemler için öngörülen zorunluluklara uyulmaksızın gerçekleştirilen işlemlerin ortadan kaldırılmasına yönelik bir karar alabilir. Bu kararının tebliğinden itibaren otuz gün içinde işlem öncesi durumun aynen sağlanmaması hâlinde Kurul tarafından SPK md. 103 gereğince idari para cezası verebilir. SPK md. 103'te SPK'ya dayanarak çıkarılan düzenlemelere ve Kurulca alınan genel ve özel nitelikteki kararlara aykırı hareket eden kişilere Kurul tarafından yirmi bin Türk Lirasından iki yüz elli bin Türk Lirasına kadar idari para cezası verileceği hükme bağlanmıştır. Ayrıca, yükümlülüğe aykırılık dolayısıyla menfaat temin edilmiş olması hâlinde verilecek idari para cezasının miktarı bu menfaatin iki katından az olamayacağı düzenlenmiştir.

Ayrıca SPK md. 103/2'ye göre ilgili düzenlemelere veya Kurul kararına aykırı hareket eden kişinin bir özel hukuk tüzel kişisinin organ veya temsilcisi olması veya organ veya temsilcisi olmamakla birlikte bu tüzel kişinin faaliyeti çerçevesinde görev üstlenen bir kişi olması hâlinde, ayrıca tüzel kişi hakkında da ilgili idari para cezası uygulanacaktır. Ancak, aykırılı̆̆ın temsilcisi olunan veya adına hareket edilen tüzel kişinin zararına bir sonuç doğurması hâlinde, tüzel kişiye idari para cezası verilmez.

Bu kapsamda önemli nitelikteki işlemler için öngörülen zorunluluklara uyulmaması halinde ilgili ortaklığa idari para cezası verilebileceği gibi, işlemi genel kurul onayına sunmayan ya da yönetim kurulu kararının yeterli olduğu hallerde usulüne uygun karar alınmasını sağlamayan yönetim kurulu üyeleri hakkında da verilebilir. ${ }^{118}$

\section{3 Önemli İşlemler Tebliği Kapsamında Yönetim Kurulu Üyelerinin Sorumluluğu}

Önemli İşlemler Tebliği md. 14'e göre, halka açık anonim ortaklıktaki yönetim kurulu üyelerinin önemli nitelikteki işlemlere ilişkin karar alınması ve işlemlerin gerçekleştirilmesi, ayrılma hakkının kullanılması ve ayrılma hakkının doğmadığı

\footnotetext{
116 Yanlı, s. 472; Manavgat, Halka Açık Anonim Ortaklıklar, s. 316.

117 Çetin/Töremiş/Cantimur, s. 204.

118 Yanlı, s. 472.
} 
hallere ilişkin tebliğde belirtilen usul ve esaslara uymak zorundadır. Yönetim kurulu üyelerinin Önemli İşlemler Tebliği'nde belirtilen hususlara uymaması durumunda ilgili tebliğ hükmüne dayanarak kendilerine karşı dava açılabilir.

\subsection{Kurul'ca SPK md. 92'deki Tedbirlerin Alınması}

SPK md. 92'ye göre SPK'ya tabi ihraççıların, kanuna, sermaye piyasası mevzuatına, esas sözleşme ve fon iç tüzüğü hükümlerine veya işletme maksat ve mevzuuna aykırı görülen durum ve işlemleri sebebiyle sermayenin veya mal varlı̆̆ının azalmasına veya kaybına yol açtı̆̆ının Kurulca tespit edilmesi halinde, Kurul'un TTK hükümleri saklı kalmak kaydıyla ilgililerden aykırılıkların giderilmesi için tedbir almasını ve öngörülen işlemleri yapmasını istemeye ve gerektiğinde durumu ilgili mercilere intikal ettirmeye yetkisi bulunmaktadır.

Örneğin, Kurul güncel mali tablo dipnotlarında yer alan ilişkili taraf açılamaları ile geçmiş dönem mali tablo dipnotlarında yer alan ilişkili taraf açıklamaları arasındaki tutarsızlıklar bulunan bir ortaklığa, SPK md. 92/1/a'daki yetkisine dayanarak ortaklığın hazırlayacağı ilk finansal tablolarda ilişkili tarafların tam ve doğru tanımlanması ve finansal tablolarda ilişkili taraf işlemlerine ilişkin açıklamaların tam ve doğru olarak yapılması hususlarında ortaklığın uyarılmasına karar vermiştir. ${ }^{119}$ Kurul'un önemli nitelikteki işlemlere ilişkin zorunlulukları yerine getirmeyen veya ayrılma hakkını kullandırmayan ortaklığa SPK md. 92/1/a kapsamında değil, SPK md. 23/2 çerçevesinde bir yaptırım uygulamasının daha isabetli olacağı değerlendirmekteyiz.

SPK md. 92/c'ye göre Kurul, kanuna, sermaye piyasası mevzuatına, esas sözleşme ve fon iç tüzüğü hükümlerine veya işletme maksat ve mevzuuna aykırı görülen ve sermayenin veya mal varlığının azalmasına veya kaybına yol açan durum ve işlemlerin mevcudiyetinin ilk derece mahkeme kararı ile tespit edilmesi veya bu karar beklenmeksizin kendi talebi üzerine mahkeme tarafindan karar verilmesi hâlinde bu işlemlerde sorumluluğu bulunanların imza yetkilerini kaldırmaya, ilgililer hakkında suç duyurusunda bulunulması hâlinde, yargılama sonuçlanıncaya kadar ilgilileri görevden almaya ve yapılacak ilk genel kurul toplantısına kadar görevden alınan yönetim kurulu üyelerinin yerine yenilerini atamaya yetkilidir.

Örneğin, ortaklık adına kayıtlı gayrimenkullerin ve menkul teçhizatın muvazaalı satıșı sonucu ortaklığın zarara uğratılmasına ilişkin bir olayda Kurul, SPK md. 92/1/a ve b bentleri uyarınca muvazaalı olarak satışı yapılan 27 adet gayrimenkulün ve menkul teçhizatın satışının iptali ile söz konusu tapu sicil kayıtlarının terkini için dava açılmasına ve söz konusu taşınmazlar ve taşınırların üçüncü kişilere devrinin engellenmesi amaciyla mahkemeden ihtiyati tedbir kararı istenmesine, SPK md. 92/1/a uyarınca muvazaalı satış sonucunda kendisine para aktarılan kişi ve şirketten söz konusu paranın yasal faizi ile birlikte ilgili kişi ve şirket nezdinde takip ve tahsil

119 Kurul'un 26.03.2013 tarihli, 2013/10 say1lı Haftalık Bülteni, http://www.spk.gov.tr/apps/haftalikbulten/displaybulten. aspx?yil=2013\&sayi=10, (Çevrimiçi), 21 Ocak 2017, s. 6. 
edilmesi için gerekli tedbirlerin alınması hususunda ortaklığın uyarılmasına ve söz konusu tutarların yasal faizi ile birlikte ortaklığa ödenmesi hususunda kendisine para aktarılan kişi ve Şirketin uyarılmasına, SPK md. 92/1/c bendi uyarınca Şirket'i zarara uğratıcı işlemlerde sorumluluğu bulunan kişinin imza yetkilerinin kaldırılmasının mahkemeden istenmesine karar vermiş̧ir. ${ }^{120}$

SPK md. 92/1/c'ya göre Kurul'a verilen geniş yetkiler çerçevesinde önemli nitelikteki işlemler için öngörülen zorunlulukları yerine getirmeyen veya ayrılma hakkını kullandırmayan ortaklığın yaptığı işlemin veya alınan genel kurul ya da yönetim kurulu kararının SPK md. 92/1'deki şartları taşıması koşuluyla, Kurul'un ilk derece mahkemesinden işlem veya kararların mevcudiyetinin tespitini istemesi, bu işlem veya kararlarda sorumluluğu bulunanların imza yetkilerinin kaldırılması konusunda mahkemeden talepte bulunması veya (sonucunda ayrılma hakkı kullandırılmayan) önemli nitelikteki işlem ile ilgili hakkında suç duyurusunda bulunulan ortaklık yönetim kurulu üyelerini yargılama sonuçlanıncaya kadar görevden alması ve ilk genel kurula kadar yerine yenilerini ataması mümkün görülmektedir.

\subsection{Pay Sahiplerinin Dava Açması}

SPK md. 23, 24 ve Önemli İşlemler Tebliği'nde halka açık anonim ortaklığın, önemli nitelikteki işlemlere ilişkin zorunlulukları yerine getirmemesi, pay sahiplerine ayrılma hakkını kullandırmaması, genel kurul gündeminde önemli nitelikteki işleme ve bu işleme karşı olumsuz oy kullanan pay sahiplerinin ayrılma hakkını kullanabileceğine ilişkin maddeye yer vermemesi veya ayrılma bedellerinin pay sahiplerine ödememesi durumunda pay sahiplerince ortaklığa karşı bir nasıl bir aksiyon alınacağı hakkında bir hüküm bulunmamaktadır.

Daha önceki konularda belirttiğimiz üzere ayrılma hakkı Türk hukukunda münferit bir hak olarak yeni tanınan bir kurumdur. Bu hakkın kullandırılmaması durumunda pay sahiplerinin dava açıp açamayacağı, açabilecek ise kimlere karşı ne tür bir dava açabileceği ve ne tür taleplerde bulunabileceği hususlarına doğrudan açıklık getiren doktrin görüşü ya da Yargitay kararı bulunmamaktadır. Bu sebeple bu sorulara cevap ararken niteliği itibariyle ayrılma hakkı ile benzer özellikler gösteren haklar için benzer durumlarda verilen yargı kararlarının ve doktrinel görüşlerin kıyasen ayrılma hakk1 için de uygulanabileceği görüşündeyiz. Yargitay 11. Hukuk Dairesi nezdinde görülen çağrı yapma zorunluluğu doğduğu halde bu zorunluluğu yerine getirmeyen pay sahiplerine karşı açılan bir davada Yüksek Mahkeme, zorunlu pay alım teklifini öngören düzenlemelerin halka açık anonim ortaklıklarda azınlıkta kalan ortaklara, ortaklıktan ayrılma hakkı tanımak amacıyla getirilmiş olduğunu ve bunun dayanağı olan kanun hükümlerinin kamu düzeninden olduğunu belirtmiş ve bu nedenle zorunlu çağrı gereğinin yerine getirilmemesi halinde, tüm azınlık pay sahiplerine firsat

120 Kurul'un 10.09.2014 tarihli 2014/26 sayılı Haftalık Bülteni, http://www.spk.gov.tr/apps/haftalikbulten/displaybulten.aspx? yil=2014\&sayi=26\&submenuheader=null, (Çevrimiçi), 22 Ocak 2017, s. 3. 
eşitliği sağlanması için, sadece bu konuda dava açan ortağın payının satılmasının sağlanmasına değil, yasa ve tebliğ doğrultusunda zorunlu aleni pay alım çağrısı yapılmasına karar verilmesi gerektiği sonucuna varmıştır. ${ }^{121}$

Önemli nitelikteki işlemler sonucunda ayrılma hakkını kullanmak isteyen pay sahibine ortaklık veya işlemden yararlanan tarafça teklifte bulunma zorunluluğu kanundan doğan bir borç niteliğindedir. ${ }^{122} \mathrm{Bu}$ nedenle ayrılma hakkını kullanmak isteyen pay sahiplerinin, bu borcu yerine getirmeyen diğer bir deyişle önemli nitelikteki işlem sonucunda pay sahiplerine ayrılma hakkını kullandırmayan ortaklığa veya Önemli İşlemler Tebliği md. 5 gereğince pay alım teklifi yapma zorunluluğu bulunan işlemden yararlanan tarafa karşı paylarının ortaklık veya işlemden yararlanan tarafça satın alınmasını konu edinen bir aynen ifa davası açma imkânının bulunduğu söylenebilir. Buna göre, ayrılma hakkını kullandırmayan ortaklık veya pay alım teklifine ilişkin yükümlülüklerini yerine getirmeyen işlemden yararlanan pay sahipleri bu teklifi mahkeme kararıyla yapmak zorunda bırakılmalıdır. Böylece, yapılacak teklif sonucunda ilgili pay sahiplerine ortaklıktan ayrılma olanağı tanınmış olacaktır. ${ }^{123}$ İlgili pay sahipleri açacakları davada paylarının satın alınmasındaki gecikme nedeniyle uğradıkları zararın tazminini de talep edebilirler. ${ }^{124}$

Ayrılma hakkı kullandırılmayan pay sahiplerinin aynen ifa davası açabileceğini belirtmekle birlikte hangi andaki pay sahiplerinin dava açma hakkının bulunduğu sorununa da çözüm getirilmesi gerekmektedir. Bu kapsamda, bir pay sahibinin dava açma hakkı bulunabilmesi için 2.2 numaralı başlık altında açıkladığımız ayrılma hakkını kullanmak için gereken tüm şartları sağlaması gerektiğini söylemek uygun olacaktır. Bu kapsamda, ayrılma hakkını doğuran önemli nitelikteki işlemin ilk defa kamuya açıklandığı veya Önemli İşlemler Tebliği md. 10/3'e göre kamuya açıklanmış kabul edildiği tarihte ortaklıkta pay sahibi olanların ayrılma hakkını kullanabileceklerini kabul etmek gerekir.

\section{Sonuç}

Hukukumuza kanuni bir düzenleme olarak 2012 yılında giren ayrılma hakk1, sadece halka açık anonim ortaklıktaki pay sahipleri için öngörülmüş bir haktır. SPK, halka açık anonim ortaklıkta gerçekleşen bazı işlemlerin pay sahibinin başlangıçta yatırım yaptığı ortaklığın temel yapısını değiştirdiği varsayımına dayanarak bazı şartları yerine getiren pay sahibine ayrılma hakkı tanımıştır. Ayrılma hakkına sebebiyet veren işlemlerin bir kısmı SPK md. 24'te önemli nitelikteki işlemler başlıklı

\footnotetext{
121 Yargıtay 11. Hukuk Dairesi'nin, 2003/3498 E., 2003/10556 K., 7.11.2003 Tarihli Kararı, (Çevrimiçi), Kazancı İçtihat Bankası, 21 Ocak 2017.

122 Manavgat, Halka Açık Anonim Ortaklıklar, s. 346, 386; Bknz. 1.2 numaralı başlık altındaki ve özellikle 8. sayfadaki açıklamalarımız.

${ }_{123}$ Mustafa Çeker, "Halka Açık Anonim Ortaklıklarda Pay Sahiplerinin Şirketten Çıkma Hakkı", Banka ve Ticaret Hukuku Dergisi, 23. C, 1. S, 2005, s. 67,68; Çağlar Manavgat, "Halka Açık Anonim Ortaklıklarda Çıkarma Ve Satma Hakkı- Sermaye Piyasası Hukukunda Yeni Yaklaşımlar”, Ticaret ve Fikri Mülkiyet Hukuku Dergisi, 1. C, 2. S, 2015, s. 104.

124 Manavgat, Halka Açık Anonim Ortaklıklar, s. 386.
} 
hükümde düzenlenmiştir. Diğer bir kısmı Önemli Nitelikteki İşlemler Tebliği'nde yer almaktadır. Bunların yanı sıra SPK' da Kurul'a belirli nitelikteki işlemleri önemli nitelikteki işlem olarak kabul etme yetkisi tanınmış, böylelikle önemli işlemler bakımından sınırlı sayı prensibi tercih edilmemiştir. Ayrılma hakkının kullanılması sonucunda ortaklık kendi payların iktisap etmekte ve pay sahibinin payları borsada işlem gören ortaklıklar ile payları borsada işlem görmeyen ortaklıklarda farklı şekillerde hesaplanan ayrılma bedeli ödenmek suretiyle ortaklık ile ilişkisine son verilmektedir. Bu sayede halka açık bir anonim ortaklıkta çoğunluğu oluşturamayan ve bu nedenle yönetime katılamayan pay sahiplerinin menfaatlerini zedeleyen kararlara karşı, ortaklıktan ayrılarak menfaatlerini koruma imkanı sağlanmıştır.

\section{KISALTMALAR LİSTESI}

A.B.D.:
Bankacılık Kanunu:
BDDK:
Birleşme ve Bölünme Tebliği:
Bknz.:
Borsa İstanbul A.Ş. Kotasyon
Yönetmeliği:
Çıarma ve Satma Hakları
Tebliği:
Geri Alınan Paylar Tebliği:
GÜHFD:
EÜHFD:
İIK:

İlişkili Taraf Tebliği:

İ̈HFD:

İ̈HFM:

KAP:

Kurul:

Kurumsal Yönetim Tebliği:

Md.:

MKK:

Önemli İşlemler Tebliği:

Pay Alım Teklifi Tebliği:

SPK:

TMK:

TTK:

vd.:

yy.:

II-16.1 Say1lı Tebliğ:
Amerika Birleşik Devletleri

5411 sayılı Bankacılık Kanunu

Bankacılık Denetleme ve Düzenleme Kurumu

Birleşme ve Bölünme Tebliği (II-23.2)

Bakınız

25502 say1l Borsa İstanbul Anonim Şirketi Kotasyon Yönetmeliği

Ortaklıktan Çıkarma ve Satma Hakları Tebliği (II-27.2)

Geri Alınan Paylar Tebliği (II-22.1)

Gazi Üniversitesi Hukuk Fakültesi Dergisi

Erzincan Üniversitesi Hukuk Fakültesi Dergisi

2004 say1lı İcra ve İflas Kanunu

İlişkili Taraf Açıklamalarına İlişkin

Türkiye Muhasebe Standardı (TMS 24)

Hakkında Teblĭg

İnönü Üniversitesi Hukuk Fakültesi Dergisi

İstanbul Üniversitesi Hukuk Fakültesi Mecmuas1

Kamuyu Aydınlatma Platformu

Sermaye Piyasası Kurulu

Kurumsal Yönetim Tebliğii (II-17.1)

Madde

Merkezi Kayıt Kuruluşu

Önemli Nitelikteki İşlemlere İlişkin Ortak Esaslar ve Ayrılma Hakkı Tebliği (II-23.1)

Pay Alım Teklifi Tebliği (II-26.1)

6362 sayılı Sermaye Piyasası Kanunu

4721 sayılı Türk Medeni Kanunu

6102 sayılı Türk Ticaret Kanunu

Ve devamı

Yüzy1l

Ortaklıkların Kanun Kapsamından Çıkarılması Ve

Paylarının Borsada İşlem Görmesi Zorunluluğuna

İlişkin Esaslar Tebliği (II-16.1) 


\section{Kaynakça}

Adıgüzel, Burak; "Halka Açık Anonim Ortaklıklarda Pay Sahibinin Ayrılma Hakkı", GÜHFD, 18. C, 2. S, 2014, s. 1-51.

Akın, İrfan; "TTK M.208 Kapsamında Anonim Şirketlerde Azınlığın Ortaklıktan Çıkarılması", GÜHFD, 17. C, S. 1-2, 2013, s. 1- 19.

Altan, Derin; "Sermaye Piyasasında Pay Sahiplerinin Ayrılma Hakkı ve Önemli Nitelikteki İşlemler”, Banka ve Finans Hukuku Dergisi, 3. C, 11. S, 2014, s. 117-161.

Altan, Derin; Acar, Nil; "Yeni Bir Alternatif Yatırım Aracı: Birleşme Amaçlı Ortaklıklar", Dokuz Eylül Üniversitesi Hukuk Fakültesi Dergisi 16. C, 1. S, 2014, s. 251-268.

Bayless, Manning; “The Shareholders's Appraisal Remedy: An Essay for Frank Coker", The Yale Law Journal, 72. C, 2. S, 1962, s. 223-265.

Bektaş, İbrahim; "Halka Açık Anonim Ortaklıkların Önemli Nitelikteki İşlemleri Nedeniyle Doğan Ayrılma Hakkı ve Pay Alım Teklifi Zorunluluğu”, Banka ve Ticaret Hukuku Enstitüsü 60. Yıl Armağanı, Ankara, Bankacılık Enstitüsü Yayınları, 2015, s.751-825.

Biçer, Levent; Hamamcıoğlu, Esra; "Anonim Ortaklıklarda Genel Kurulun Devredilemez Yetkileri Kapsamında Önemli Miktarda Şirket Varlığının Toptan Satışı ve Uygulama Alanı”, KHÜHFD, 1. C, 1. S, 2013. S. 34- 51.

Bilgi, Mehmet Emin; “Anonim Şirketin Sona Ermesi ve Tasfiyesi”, EÜHFD, 16. C, 3-4. S, 2012, s. 261-294.

Bilgili, Fatih; Demirkapı, Ertan; Şirketler Hukuku, 9. Bs, Bursa, Dora Yayımevi, 2013.

Coştan, Hülya; Anonim Ortaklıklarda Bölünme, Turhan Kitabevi, Ankara, 2004.

Çeker, Mustafa; “Ticaret Şirketlerinin Genel Hükümleri ve Yeniden Yapılandırılmaları”, EÜHFD, s. 99-120.

Çeker, Mustafa; "Halka Açık Anonim Ortaklıklarda Pay Sahiplerinin Şirketten Çıkma Hakkı", Banka ve Ticaret Hukuku Dergisi, 23. C, 1. S, 2005, s.61-73.

Çetin, Nusret; Töremiş, Hatice Ebru; Cantimur, Zeynep; Sermaye Piyasası Kanunu'nun Sistematik Analizi, Ankara, Yetkin Yayınları, 2014

Kanda, Hideki; Levmore, Saul; "The Appraisal Remedy and the Goals of Corporate Law", University of California Los Angeles Law Review, 32. C, 1985, s. 429-473.

Kraakman Reinier; Armour, John; Davies, Paul; Enriques, Luca; Hansmann, Henry; Hertig, Gerard; Hopt, Klaus; Kanda, Hideki; Rock, Edward; The Anatomy of Corporate Law, 2. bs., New York, Oxford University Press, 2009.

Levy, J. Irving; "Rights of Dissenting Shareholders to Appraisal and Payment", Cornell Law Review, 420. C, 1930, s. 420-444.

Manavgat, Çağlar; Halka Açık Anonim Ortaklıklar ve Halka Arz, Ankara, Banka ve Ticaret Hukuku Araştırma Enstitüsü, 2016. (İlgili eser makalede "Halka Açık Anonim Ortaklıklar" şeklinde kısaltılmıştır.)

Manavgat, Çağlar; "Türk Ticaret Kanunu Hükümlerinin Halka Açık Anonim Ortaklıklara Uygulanması Ve Sinırları”, İ̈̈HFM, 71. C, 2. S, 2013, s. 287-298.

Manavgat, Çağlar; "Halka Açık Anonim Ortaklıklarda Çıkarma Ve Satma Hakkı- Sermaye Piyasası Hukukunda Yeni Yaklaşımlar", Ticaret ve Fikri Mülkiyet Hukuku Dergisi, 1. C, 2. S, 2015, s. 93-106.

Memiş, Tekin; Turan, Gökçen; Sermaye Piyasası Hukuku, 2.bs., Ankara, Seçkin Yayıncılık, 2016. 
Oğuzman, Kemal; Barlas, Nami; Medeni Hukuk, İstanbul, Vedat Kitapç1lık, 2015.

Okutan Nilsson, Gül; Sermaye Piyasası Hukukunda Birleşme Amaçlı Ortaklık, Onİki Levha Yayınc1lik, İstanbul, 2016.

Özdamar, Mehmet; “Anonim Ortaklığın Sahip Olduğu Malvarlığının Yönetim Kurulu Tarafından Topluca Devredilmesi”, SÜHFD, 14.c, 2.s, 2006, s. 99-118.

Özdoğan, Ayşegül; "Halka Açık Anonim Ortaklıklarda Pay Sahibinin Ortaklıktan Ayrılma Hakkı", Cumhuriyetin 80. Yılına Armağan, 2.C, Ankara, Sermaye Piyasası Kurulu, 2004, s. 691-764.

Paslı, Ali; Anonim Ortaklığın Devralınması, Vedat Kitapçılık, İstanbul, 2009.

Pulaşl,,Hasan; "Yeni Türk Ticaret Kanunu'na GöreAnonim Şirkette İmtiyazlı Paylar”,,(Çevrimiçi)http:// www.kazanci.com/kho2/hebb/files/dsp.php?fn=makale-hasanpulasli-1.htm\&kw='imtiyaz’\#fm, 5 Ocak 2017.

Sönmez, Yusuf; Anonim Ortaklıklarda Pay Sahibinin Ortaklıktan Ayrılma Hakkı, İstanbul, Beta Yayınc1lik, 2009.

Tekinalp, Ünal; Sermaye Ortaklıklarının Yeni Hukuku, 3. Bs., İstanbul, Vedat Kitapç1lık, 2013.

Uzunallı, Sevilay; Anonim Şirkette İşletme Konusu, Ankara, Adalet Yayınevi, 2013.

Yanlı, Veliye; "Halka Açık Şirketlerde Önemli Nitelikteki İşlemler”, IÜHFD, 6. C, 2. S, 2015, s. 459- 472.

Yeşiltepe, Salih Önder; Halka Açık Anonim Ortaklıklarda Çıkarma ve Satma Hakları, 2. Bs., Ankara, Seçkin Yayıncılık, 2015.

Wertheimer, Barry M.; “The Shareholders' Appraisal Remedy And How Courts Determine Fair Value", Duke Law Journal, 47. C, 4. S, 1998, s. 613-712.

\section{Elektronik Kaynaklar}

Kurul'un 15.05.2013 tarihli, 2013/16 sayılı Haftalık Bülteni: http://www.spk.gov.tr/apps/haftalikbulten/ displaybulten.aspx?yil=2013\&sayi=16\&submenuheader=null, (Çevrimiçi), 9 Ocak 2017.

Kurul'un 26.03.2013 tarihli, 2013/10 sayılı Haftalık Bülteni: http://www.spk.gov.tr/apps/ haftalikbulten/displaybulten.aspx?yil=2013\&sayi=10, (Çevrimiçi), 21 Ocak 2016, s. 6.

Kurul'un 10.09.2014 tarihli 2014/26 saylı Haftalık Bülteni: http:/www.spk.gov.tr/apps/haftalikbulten/ displaybulten.aspx?yil=2014\&sayi=26\&submenuheader=null, (Çevrimiçi), 22 Ocak 2016, s. 3.

Kurul'un bir davaya ilişkin olarak aldığı 18.05.2015 ve 1179 sayılı ve 21.10.2015 ve 11462 sayılı Kararları ve Bakırköy 1. Asliye Ticaret Mahkemesi'ne sunulan 11.05.2016 tarihli Ek Bilirkişi Raporu: https://www.kap.org.tr/tr/Bildirim/536241, (Çevrimiçi), 10 Ocak 2017.

SPK Gerekçesi: https://www.tbmm.gov.tr/sirasayi/donem24/yil01/ss337.pdf

Türkiye Muhasebe Standartları 24 İlişkili Taraf Açıklamaları: http://www.kgk.gov.tr/contents/ files/TFRS_2016/TMS/TMS24.pdf

Yargıtay 11. Hukuk Dairesi'nin 2003/3498 E., 2003/10556 K., 7.11.2003 tarihli Kararı ( Kazancı İçtihat Bankası) 